\title{
Where the whales are: using habitat modeling to support changes in shipping regulations within National Marine Sanctuaries in Central California
}

\author{
Andrea Dransfield ${ }^{1,2}$, Ellen Hines ${ }^{1,3}$, Jennifer McGowan ${ }^{1,2}$, Barbara Holzman ${ }^{3}$, \\ Nadav Nur ${ }^{2}$, Meredith Elliott ${ }^{2}$, Julie Howar ${ }^{2}$, Jaime Jahncke ${ }^{2, *}$ \\ ${ }^{1}$ Romberg Tiburon Center for Environmental Studies, Tiburon, California 94920, USA \\ ${ }^{2}$ Point Blue Conservation Science, Petaluma, California 94954, USA \\ ${ }^{3}$ San Francisco State University, San Francisco, California 94132, USA
}

\begin{abstract}
Understanding habitat preferences for endangered species is a high priority for management strategies to ensure minimum conflict between human uses and wildlife conservation. The purpose of this study was to identify oceanographic variables that predict occurrences of humpback whales Megaptera novaeangliae within the Cordell Bank and Gulf of the Farallones National Marine Sanctuaries, California, USA, to assess potential conflict with vessel traffic. We used data collected by Applied California Current Ecosystem Studies (ACCESS) conducted from 2004 to 2011. Using zero-inflated negative binomial regression, we developed predictive models and identified locations highly used by whales to characterize humpback whale habitat. We analyzed whale encounter rates at $3-\mathrm{km}$ bin intervals in relation to bathymetric, surface and midwater hydrographic predictor variables and temporal variables characterizing oceanographic conditions. Our models included variables that accounted for detectability of whales. Two models were compared and contrasted: (1) a surface-only model, using only surface oceanographic variables, and (2) a surface + mid-water model, using both surface and mid-water variables. The surface + mid-water model performed significantly better than the surface-only model, which underestimated the amount of suitable whale habitat in the northern half of our study area. We compared resulting predicted habitat areas with previous and current San Francisco Bay Area shipping lane polygonal footprints to investigate whether newly accepted changes in routes reduced areal overlap with humpback whale habitat. Although our analyses show that the area occupied by shipping traffic has decreased in areas of high predicted humpback whale habitat use, changes in vessel lane footprints do not account for several important aspects of ship-strike risk, including vessel frequency, speed, size and density patterns within the shipping lanes and variability between lanes.
\end{abstract}

KEY WORDS: Humpback whale $\cdot$ Habitat modeling $\cdot$ Ship strikes $\cdot$ Habitat suitability $\cdot$ Shipping lanes · Generalized linear model · Geographic information system · Zero-inflated negative binomial regression

\section{INTRODUCTION}

Whales remain subject to a multitude of anthropogenic threats including acoustic disturbance, ship strikes, habitat degradation, resource competition with humans, climate change and entanglement in

${ }^{*}$ Corresponding author: jjahncke@pointblue.org fishing gear (Calambokidis \& Barlow 2004, Calambokidis et al. 2008, Reilly et al. 2008). Vessel collisions with large whales are a growing international problem (Clapham et al. 1999), and research on modeling ship strike risk is on the rise (Williams \& O'Hara 2010, Wade et al. 2011, Wiley et al. 2011, Reeves et

(C) The authors 2014. Open Access under Creative Commons by Attribution Licence. Use, distribution and reproduction are unrestricted. Authors and original publication must be credited. 
al. 2012, Conn \& Silber 2013, Redfern et al. 2013). The number of whale ship strikes is increasing due to larger and faster commercial vessels (Knowlton \& Brown 2007). Ship strikes in the North Atlantic have had a pronounced effect on the already small population of endangered North Atlantic right whales Eubalaena glacialis (Knowlton \& Kraus 2001). Right whale habitat coincides with shipping traffic lanes and has resulted in approximately 2 reported whale collisions per year, making this one of the leading causes of death for this species (Knowlton \& Brown 2007).

Similarly, on the west coast of the United States, ship strikes are an important cause of mortality for baleen whales, including humpback (Megaptera novaeangliae), blue (Balaenoptera musculus), fin (Balaenoptera physalus) and gray whales (Eschrichtius robustus) (Berman-Kowalewski et al. 2010). Our study was conducted on the central California coast (Fig. 1) where 20 documented reports from 1988 to 2011 reflect large whale ship strikes in the Gulf of the Farallones National Marine Sanctuary (GFNMS) and the Cordell Bank National Marine Sanctuary (CBNMS) (NMFS 2010). These numbers are probably underestimates since many collisions are not reported, often due to a low probability of detection (Laist et al. 2001, Kraus et al. 2005). It is estimated that the incidence of ship strikes could be at least 10 times higher than the number documented (Williams et al. 2011). In the sanctuaries, there are 3 designated shipping lanes approaching from the north, west and south (Fig. 2A). In June 2013, newly modified shipping lanes went into effect, approved by the International Maritime Organization (M. Carver, Deputy Superintendent of Cordell Bank NMS, pers. comm.). The configuration of these modified lanes were based on joint recommendations from the GFNMS and CBNMS Joint Working Group on Vessel Strikes and Acoustic Impacts and The United States Coast Guard (USCG) to improve navigational safety while reducing overlap between whales and ship traffic (Fig. 2B) (Joint Working Group on
Vessel Strikes and Acoustic Impacts 2012). Although our study was not available at the time that changes in the shipping lanes were implemented, investigating where whale habitats are in relation to the current shipping lanes will help inform the effectiveness of these vessel traffic adjustments in the sanctuaries.

Identifying important whale feeding grounds and determining why these areas are preferentially chosen is an important question in ongoing cetacean re-

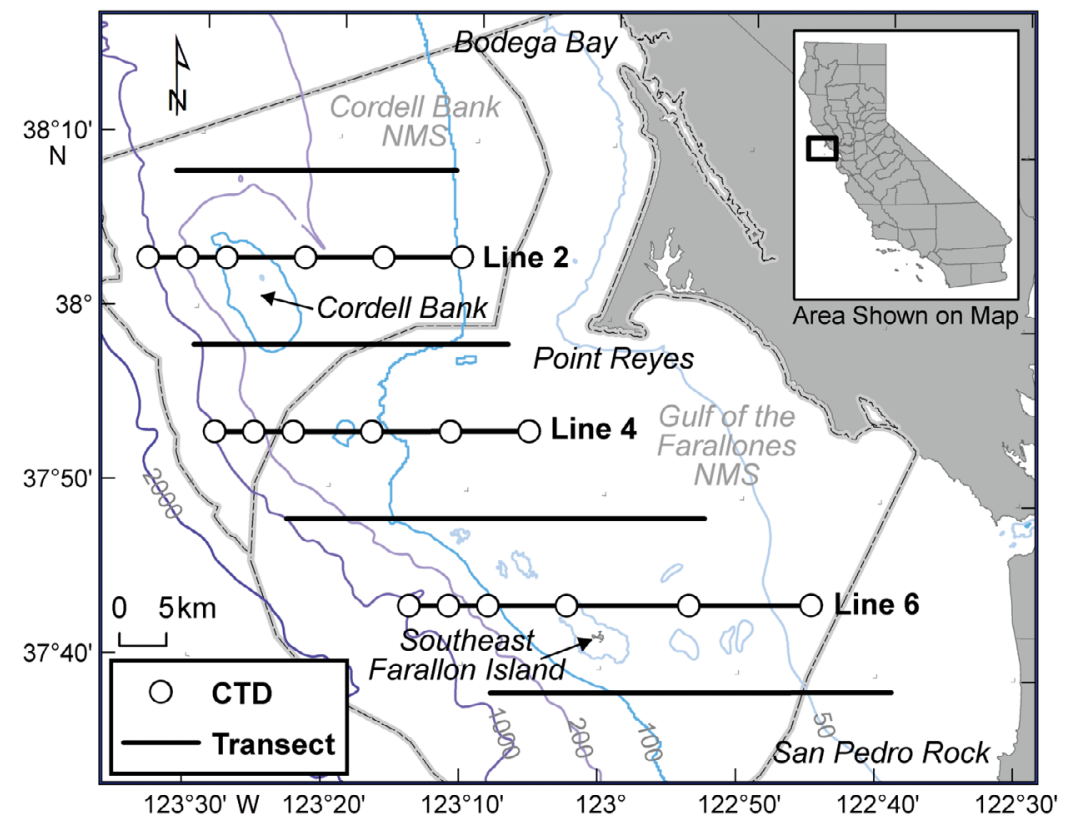

Fig. 1. Study area within the Cordell Bank and Gulf of the Farallones National Marine Sanctuaries (NMS), California, USA, showing transect lines and oceanographic sampling (CTD) stations

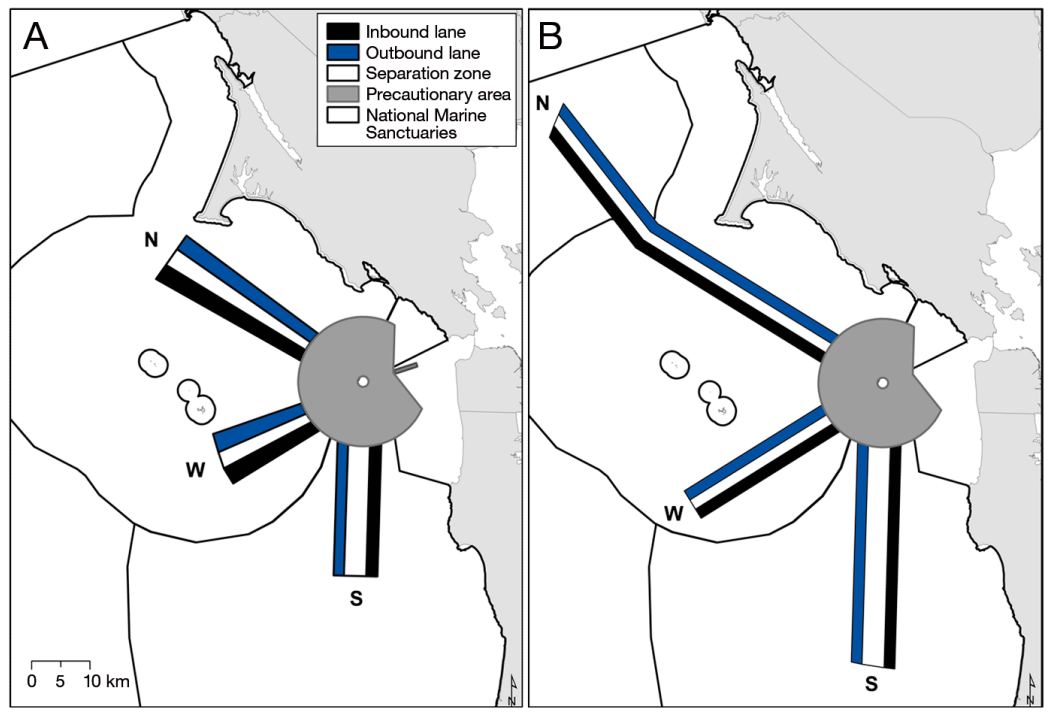

Fig. 2. (A) Previous (pre-2013) and (B) current shipping lane configurations off San Francisco Bay showing the northern (N), western (W) and southern (S) approaches, and the inbound and outbound lanes 
search (Kerosky et al. 2008). Identifying these habitats can improve conservation efforts by focusing management on these critical areas. Whale habitats have been characterized in terms of oceanography (i.e. water properties), bathymetry (i.e. depth and shelf break), climate (i.e. El Niño) and prey availability (Yen et al. 2004, Friedlaender et al. 2006, Becker et al. 2010, 2012, Forney et al. 2012). Yet, despite many studies on abundance and distribution (e.g. Keiper et al. 2005, Williams \& Thomas 2007), photo identification (Calambokidis et al. 2001, Barlow et al. 2011) and habitat use, the factors driving habitat selection often remain poorly understood due to the dynamic nature of marine species affected by oceanic processes that drive prey availability (McGowan et al. 2013).

Habitat models are important tools for linking cetacean observations to ecological variables and identifying critical habitat, and can be used in developing spatial management strategies for highly mobile species (Dalla Rosa et al. 2012, Gregr et al. 2013, Redfern et al. 2013). Humpback whales migrate annually from their summer feeding grounds in temperate and subpolar waters where they feed on krill and fish, to their winter breeding grounds in low latitude tropical waters (Johnston et al. 2007, Rasmussen et al. 2007, Calambokidis et al. 2008). They have the longest migration of any mammal (Rasmussen et al. 2007). There is strong site fidelity to both wintering and feeding grounds, which is particularly marked in female whales (Calambokidis et al. 2008). California is a recognized feeding area for this species (Barlow et al. 2011), and humpback whales are present at highly productive areas along the coast including the CBNMS and GFNMS, where they are sighted from April to early December during their migratory cycle (Yen et al. 2004, Keiper et al. 2005).

The humpback whale is listed under the US Endangered Species Act as 'endangered' and the Marine Mammal Protection Act as 'depleted' throughout its range (NMFS 1991). Humpback whales are also protected under Appendix I of the Convention on International Trade in Endangered Species and in Appendix II of the Convention on Migratory Species (www. speciesplus.net/species). The International Union for Conservation of Nature's Red List shows a designation of 'Least Concern' after a status change from 'Vulnerable' in 2008 (IUCN 2012). This change in designation was due to population numbers increasing in the $10 \mathrm{yr}$ since the previous assessment, the availability of more abundance data, and a threshold reduction in the 'Vulnerable' criteria (Reilly et al. 2008). However, due to deficient data, this designa- tion does not reflect all subpopulations. For example, prior to commercial exploitation, the North Pacific humpback whale population was estimated to be about 15000 whales, but this number is likely higher because of the possibility of inaccurate whaling accounts (Calambokidis et al. 2008). Currently, in the California and Oregon region, the best estimate is 2043 humpback whales (Carretta et al. 2013).

Several previous studies have modeled associations between humpback whales and bathymetric and oceanographic properties on the west coast of the USA (Yen et al. 2004, Barlow et al. 2009, Becker et al. 2012, Dalla Rosa et al. 2012, Forney et al. 2012). Many cetacean habitat models have relied on surface water properties derived from coarse-scale remotely sensed data (Gregr \& Trites 2001, Claridge 2006, Johnston et al. 2007, Embling et al. 2010). Yet, determining areas that require protection at appropriate scales for National Marine Sanctuary management necessitates a finer understanding of humpback habitat than remotely sensed data can provide (Redfern et al. 2006, 2013, Hirzel \& Le Lay 2008, Barlow et al. 2009, Dalla Rosa et al. 2012). Further, because whales forage throughout the water column and prey species may be present at multiple depths (Hopkins 1982, Croxall et al. 1985, Croll et al. 2005), consideration of subsurface oceanic properties provides a more complete picture of humpback whale habitats. This is due to the availability of prey species decreasing in warmer nutrient-poor surface waters relative to the pycnocline, where mid-water layers are colder and more nutrient rich (Cullen 1982). Studies have examined cetacean relationships with thermocline topography (Reilly 1990, Reilly \& Fiedler 1994, Redfern et al. 2008), the vertical migration of copepods (Baumgartner 2003, Baumgartner \& Fratantoni 2008), and water column data, surface data and bathymetry (Ferguson et al. 2006). Similar studies in California examined relationships between whales and oceanographic properties and included subsurface oceanic properties (Benson et al. 2002, Becker et al. 2012, Redfern et al. 2013). Despite the importance of this information in understanding how management actions, such as a change in shipping lanes, can potentially affect whales in the sanctuaries, modeling of fine-scale, high-use habitat for humpback whales has yet to be accomplished. We define high-use habitat as areas with high probability of presence or high abundance during certain seasons (Keiper et al. 2005, McGowan et al. 2013).

Here, we use 8 yr of humpback whale sightings in the sanctuaries, combined with fine-scale in situ data of surface and mid-water oceanographic properties, 
to develop predictive models and identify locations highly used by humpback whales. We also generated and tested models to assess whether adding midwater oceanographic variables significantly improves model predictions, relative to using surface-only variables. Results were overlaid upon previous and current San Francisco Bay Area shipping lane configurations to assess changes in areal overlap between modeled whale habitat and vessel traffic lane polygons.

\section{MATERIALS AND METHODS}

\section{Study area}

The CBNMS and the GFNMS are located off the west coast of the USA in central California (Fig. 1). The CBNMS was established in 1989 with an area of 529 miles $^{2}\left(1370 \mathrm{~km}^{2}\right.$ ) (Office of National Marine Sanctuaries 2009). The prominent seamount is situated 12.4 miles $(20 \mathrm{~km})$ northwest of the northern Farallon Islands (Yen et al. 2004). The GFNMS was established in 1981 and encompasses 1282 miles $^{2}$ $\left(3320 \mathrm{~km}^{2}\right)$ just north and west of San Francisco Bay (Office of National Marine Sanctuaries 2010). These 2 adjoining sanctuaries are within the dynamic California Current System, known as one of the most productive marine environments in the world (Hickey \& Banas 2008, Jahncke et al. 2008).

\section{Data collection}

Humpback whale data were collected during Applied California Current Ecosystem Studies (ACCESS) cruises conducted by Point Blue Conservation Science (formerly the Point Reyes Bird Observatory) and the National Oceanic and Atmospheric Administration (NOAA) (Jahncke et al. 2008, Michael et al. 2014). These cruises are a collaborative effort to survey marine birds and mammals along the central California coast. There were 29 cruises from May 2004 through September 2011, coinciding with months of whale presence where whales are foraging, feeding on krill and fish (Yen et al. 2004). The time scale for each cruise was 3 to $5 \mathrm{~d}$. ACCESS survey design consists of 26 systematically placed parallel transects that span the continental shelf and slope to cover nearshore and offshore areas between southern Bodega Bay and San Pedro Rock. The offshore transects 1 to 7 were analyzed in this study as they are the most frequently surveyed (Fig. 1). Sur- veys were conducted on 3 research vessels (R/V) with varying flying bridge heights: the smallest is R/V John Martin (3.6 m), with R/V NOAA Fulmar $(5.5 \mathrm{~m})$ in the middle and R/V McArthur II (14.4 m) the largest. Surveys used standardized strip-survey methods (see Jahncke et al. 2008 for further details) where marine mammal sightings directly ahead of the vessel in a $180^{\circ}$ arc from port to starboard and out to the horizon were recorded continuously by 2 observers stationed on each side of the flying bridge while the survey vessel was under way (Yen et al. 2004, Barlow et al. 2009, Redfern et al. 2013). Any observations made by the naked eye were confirmed with binoculars. This survey method conventionally assumes that all whales present within the survey area are counted by the observers; however, our analytic approach does not make this assumption. We do not assume that all whales present with the survey area are counted by observers, and instead have used zero-inflated negative binomial regression to account for 'false zeros' (i.e. failure to detect an individual that is indeed present). As detection ability varies with weather, environmental conditions (i.e. Beaufort scale) at the time of the survey were simultaneously recorded, and transects surveyed in unfavorable conditions of Beaufort 6 or higher were omitted from this study. We further discuss the factors influencing detectability in the data analysis section.

All humpback whale counts and weather-related data along transects were aggregated into $3 \mathrm{~km}$ linear segments, referred to as bins. Previous studies investigating spatial autocorrelation for this data set concluded $3 \mathrm{~km}$ bins to be an appropriate size (Yen et al. 2004, Nur et al. 2011). Small bin sizes occasionally arose at the end of transect lines; bins $<1 \mathrm{~km}$ in length were removed from the final data set to avoid introducing errors that may result from including unreliable and uncertain estimates of encounter rates (Michael et al. 2014).

Oceanographic data including temperature, salinity and fluorescence were collected using a Sea-Bird Electronics SBE 19Plus SEACAT Conductivity Temperature Depth (CTD) profiler equipped with a WETStar fluorometer at designated oceanographic stations (Fig. 1). Data values were averaged at $1 \mathrm{~m}$ depth intervals and sorted according to depth in the water column. Data were collected throughout the water column but for the purposes of this analysis, we averaged the data for surface $(<10 \mathrm{~m})$ and mid-water (30 to $40 \mathrm{~m}$ ) layers. These layers were chosen based on areas of primary productivity in the photic zone and because both of these layers can extend over the entire study area given that it becomes shallower as 
you approach land. Humpback whales forage at depths between 20 and $120 \mathrm{~m}$ in the water column (Goldbogen et al. 2008), and therefore including midwater properties constructs a more complete analysis of habitat use. Bathymetric data (200 m bathy-topo grid) for California were obtained from the Department of Fish and Wildlife Marine Region GIS Unit (www.dfg.ca.gov/marine/gis/downloads.asp). The California and Sanctuary boundary shapefiles were accessed from the National Marine Sanctuary Geographic Information System Dataset (www.sanctuaries. noaa.gov/library/imast_gis.html). Regional oceanographic conditions are linked to patterns of local climate variability (Schwing et al. 2010) and for this reason, we included the following climate indices: (1) the Upwelling Index (UI) from the Pacific Fisheries Environmental Laboratory, which is a measure of the volume of water that upwells along this coastal region (Bakun 1973; www.pfeg.noaa.gov); (2) the Southern Oscillation Index (SOI) which measures the largescale fluctuations in sea level pressure anomalies occurring between the western and eastern tropical Pacific during El Niño and La Niña episodes (Trenberth 1984, www.cgd.ucar.edu/cas/catalog/climind/ SOI.signal.ascii); (3) the Pacific Decadal Oscillation (PDO), which is the leading principal component of monthly sea surface temperature variability in the North Pacific, north of $20^{\circ} \mathrm{N}$ (Mantua et al. 1997; http://jisao.washington.edu/pdo/); and (4) the North Pacific Gyre Oscillation (NPGO), which affects sea surface height and is correlated with fluctuations in salinity, nutrients and chlorophyll a (Di Lorenzo et al. 2008; http://eros.eas.gatech.edu/npgo/). The 10-d average of daily upwelling up to and including the last day of data collection for each cruise was assigned to each bin midpoint. Monthly values of the other climate indices for each cruise were assigned to each bin midpoint.

Current and previous shipping lane configuration shapefiles were provided by Stellwagen Bank National Marine Sanctuary. We hand-digitized shipping lane footprints in a geographic information system (GIS) based on Automatic Identification System (AIS) data compiled by the USCG's National AIS Program (Thompson 2009). This data set provides details on the behavior of vessels over 300 tons that are approaching or leaving San Francisco Bay through the sanctuaries (Joint Working Group on Vessel Strikes and Acoustic Impacts 2012). Vessel tracks lead to a precautionary area that marks the beginning of the main channel to the Golden Gate Bridge (Fig. 2B). Shipping lanes are voluntary but ships regularly use one of these 3 lanes to enter into the San
Francisco Bay because of insurance regulations. Ships converge and diverge from the lanes in a multitude of angles.

\section{Data processing}

Oceanographic data values for temperature, salinity and fluorescence for the surface and mid-water columns were interpolated using ordinary kriging in ArcGIS (10.0, ESRI) on a cruise-by-cruise basis, resulting in a total of 174 layers ( 3 variables $\times 29$ cruises $\times 2$ depth layers). Kriging is used across disciplines and has gained popularity in interpolating surfaces in the marine environment (Barlow et al. 2009, Forney et al. 2012). This method uses an advanced semivariogram to determine weights, is ideal for identifying spatial patterns in a patchy environment, and produces the most accurate estimates (Johnston et al. 2001, Reese \& Brodeur 2006, Bello-Pineda \& Hernández-Stefanoni 2007). The parameters from interpolated layers were optimized to minimize the mean square error and improve predictive capability, thus assisting in the fitting of the semivariogram (Johnston et al. 2001). Outliers were identified by graphing the root mean square errors of predictions and 2 standard deviations above and below the mean, and detrended when necessary to minimize error in the analysis.

Whale counts were overlaid on oceanographic and bathymetric layers to extract covariate data at appropriate time and spatial scales. See Fig. 3 for a flow chart of methods. For each $3 \mathrm{~km}$ bin midpoint, we extracted oceanographic data for temperature, salinity and fluorescence for surface and mid-water layers on a cruise-by-cruise basis, sampled bathymetric data for depth, and calculated distance to the $200 \mathrm{~m}$ isobaths, the mainland, the Farallon Islands and the center of Cordell Bank. We then assigned corresponding monthly values for the regional climate indices (UI, SOI, PDO and NPGO) and retained the original environmental conditions recorded at each bin midpoint. The $200 \mathrm{~m}$ isobath was chosen because it represents the continental shelf edge, which has been found to be an important habitat feature for cetaceans in other studies (Yen et al. 2004, Tynan et al. 2005, Friedlaender et al. 2006, Dalla Rosa et al. 2012).

\section{Data analysis}

Combining GIS tools with statistical analysis increases our understanding of species' habitat use and 


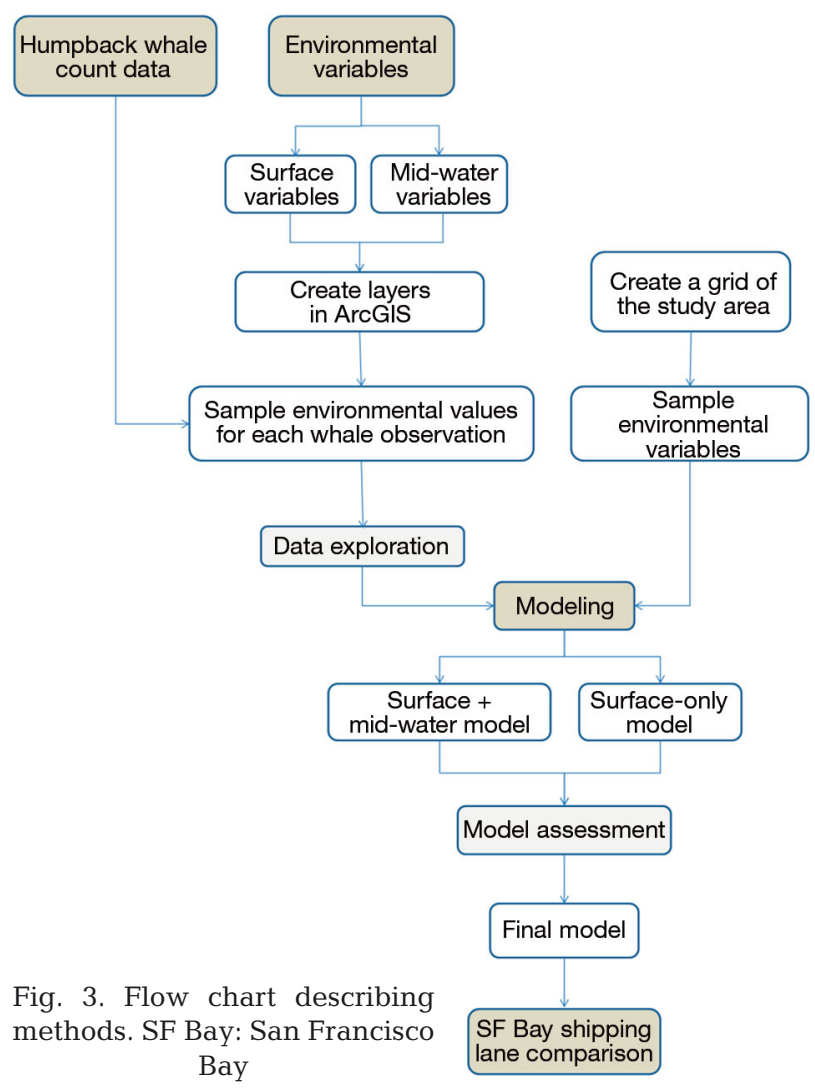

allows us to predict preferred habitat (Claridge 2006). Whale counts were modeled using zero-inflated negative binomial regression as a function of oceanographic, bathymetric and climate covariates, in addition to month (coded from 5 to 10, treated as a quadratic) and year (treated as a categorical variable) in Stata 10 (Table 1) (Statacorp 2007). Negative binomial regression modeling is recommended when analyzing data that have a larger proportion of zeros than expected from Poisson-distributed data (Barry \& Welsh 2002, Yau et al. 2003, Cunningham \& Lindenmayer 2005, Potts \& Elith 2006, Elith \& Leathwick 2009, Zuur et al. 2013). Excess zeros commonly occur in field-collected data as observation records may include false zeros as a result of survey detection errors (i.e. a whale was present but not detected or an individual was absent from suitable habitat, leading to an excessively high frequency of zeros in the data (Zuur et al. 2013)). Failing to account for excess zeros can result in problematic inferences and incorrect assumptions of species-habitat associations (Barry \& Welsh 2002, Potts \& Elith 2006). Zero-inflated models provide a better fit as they account for both true (unsuitable habitat) and false zero observations (Zuur et al. 2009). We refer to the environmental factors leading

Table 1. All candidate predictor variables evaluated in the analyses. Models also included year (as categorical) and month (as quadratic)

\begin{tabular}{|c|c|c|c|}
\hline Variable & Mean $\pm \mathrm{SD}$ & Min-max values & Data source \\
\hline \multicolumn{4}{|l|}{ Oceanographic } \\
\hline Surface fluorescence $\left(\mathrm{mg} \mathrm{m}^{-3}\right)$ & $8.6 \pm 10.2$ & 0 to 60.9 & Shipboard \\
\hline Surface temperature $\left({ }^{\circ} \mathrm{C}\right)$ & $11.9 \pm 1.56$ & 8.4 to 15.67 & Shipboard \\
\hline Surface salinity (psu) & $33.4 \pm 0.32$ & 31.92 to 34.12 & Shipboard \\
\hline Mid-water fluorescence $\left(\mathrm{mg} \mathrm{m}^{-3}\right)$ & $5.92 \pm 5.36$ & 0.30 to 55.98 & Shipboard \\
\hline Mid-water temperature $\left({ }^{\circ} \mathrm{C}\right)$ & $10.53 \pm 1.19$ & 7.95 to 13.98 & Shipboard \\
\hline Mid-water salinity (psu) & $33.56 \pm 0.29$ & 32.58 to 34.08 & Shipboard \\
\hline \multicolumn{4}{|l|}{ Bathymetric } \\
\hline Depth $(\mathrm{km})$ & $-0.66 \pm 0.92$ & -6.04 to 0 & California Dept of Fish and Wildlife (2012) \\
\hline Distance to 200 m isobath (m) & $9232.66 \pm 7892.11$ & 13.6 to 41170.32 & Calculated in ArcGIS \\
\hline Distance to Cordell Bank (m) & $28103.46 \pm 17731.22$ & 806.92 to 78899.02 & Calculated in ArcGIS \\
\hline Distance to mainland (m) & $27610.86 \pm 8712.78$ & 802.54 to 47361.56 & Calculated in ArcGIS \\
\hline Distance to islands (m) & $21778.58 \pm 13031.61$ & 56.38 to 49418.39 & Calculated in ArcGIS \\
\hline \multicolumn{4}{|l|}{ Climate indices } \\
\hline Southern Oscillation Index & $0.41 \pm 1.76$ & -2.7 to 4.3 & $\begin{array}{l}\text { CGD University Corporation for Atmos- } \\
\text { pheric Research }\end{array}$ \\
\hline Pacific Decadal Oscillation & $-0.1 \pm 1.01$ & -1.8 to 1.86 & $\begin{array}{l}\text { Joint Institute for the Study of the } \\
\text { Atmosphere and Ocean }\end{array}$ \\
\hline North Pacific Gyre Oscillation & $0.40 \pm 0.99$ & -1.48 to 2.23 & www.o3d.org/npgo/ \\
\hline Upwelling Index & $92.57 \pm 42.81$ & 6.41 to 178 & $\begin{array}{l}\text { Pacific Fisheries Environmental Labora- } \\
\text { tory (2012) }\end{array}$ \\
\hline \multicolumn{4}{|l|}{ Detection variables } \\
\hline Sea state (Beaufort) & $2.67 \pm 1.35$ & 0 to 6 & Shipboard \\
\hline Visibility & $5.61 \pm 2.1$ & 0 to 9 & Shipboard \\
\hline Swell height (m) & $1.98 \pm 5.07$ & 0 to 8 & Shipboard \\
\hline Cloud cover & $5.21 \pm 3.37$ & 0 to 9 & Shipboard \\
\hline Time of day (h:min:s) & $12: 17: 00 \pm 03: 04: 00$ & 06:08:01 to $20: 05: 41$ & Shipboard \\
\hline
\end{tabular}


to zero inflation in our analysis as detection bias variables.

After checking for collinearity between variables (variance inflation factor [VIF] test $<3$ indicates collinearity not of concern; Zuur et al. 2013), we conducted univariate testing using negative binomial regression to determine whether linear or non-linear relationships existed between whale counts and each separate covariate. In all cases, we used the log of bin sizes as an offset coefficient in all models to account for variable bin lengths (1 to $3 \mathrm{~km}$ ) and thus differences in rates of detection across surveyed bins. All potential covariates were first included in a preliminary negative binomial regression model. We then used a manual backwards stepwise approach to identify the significant predictor variables ( $p \leq 0.05$ for retaining a variable in the initial model) (Yen et al. 2004, Franklin 2009). All significant variables retained from the first phase were then added to a zeroinflated negative binomial regression model that also included detection bias variables (Table 1), which accounted for unfavorable sighting conditions that likely biased humpback whale sightings. We used the Vuong statistic to confirm whether to use the zero-inflated negative binomial regression versus standard negative binomial regression (Long 1997). Habitat variables that were significant in the initial multi-variable model (which did not include sea state and visibility) were retained in the zero-inflated regression model even if they were no longer significant in the latter model, provided they met a secondary criterion: inclusion of the habitat variable is justified using Akaike's information criterion (AIC) (Zuur et al. 2009). We decided to be conservative and include variables for which there was ambivalent support (i.e. significant in the initial multi-variable model even though not significant in the final model with sea state and visibility, provided inclusion was justified by AIC).

We repeated these steps to create a surface + midwater model (surface and mid-water variables) and a surface-only model (surface variables only) (Fig. 3); both models included temporal (year, month), oceanographic and the 2 detectability variables. Final models were compared using likelihood ratio test statistics (LRS; Hosmer \& Lemeshow 2000, Beal 2005). A likelihood ratio test is a statistical test used to compare the fit of 2 models, one of which is nested within the other. The test is based on the likelihood ratio, which expresses how many times more likely it is to obtain the data under one model compared with the other. To assess the fit of the surface + mid-water and surface-only models, we used $n$-fold cross-validation, which randomly splits binned observations into mutually exclusive subsets (Kohavi 1995). Cross-validation was accomplished by leaving 1 subset out each time, with 10 replications (10-fold cross-validation). We controlled for differences among months and among years. However, because sample sizes were relatively small in most years, the data set was not sufficient to analyze the interaction of year with each of the covariates (bathymetric, hydrographic or climate). Whereas the number of non-zero observations (i.e. bins) was 275 across the $8 \mathrm{yr}$, it was $<30$ for 5 of the $8 \mathrm{yr}$, which presents a problem in estimating and evaluating differences among years. Our models thus indicate the overall effect across all years for each of the variables included in the model.

Surface + mid-water and surface-only models were used to predict and map humpback whale abundance on a $1 \mathrm{~km}^{2}$ raster grid (Guisan \& Thuiller 2005, Beekmans et al. 2010, Viddi et al. 2010, Hazen et al. 2011, McGowan et al. 2013). The grid extended to the boundaries of the National Marine Sanctuaries with an additional $5 \mathrm{~km}$ buffer beyond sanctuary boundaries to incorporate waters bordering our study area. This grid cell size was chosen because such a scale was deemed desirable given the objectives of delineating whale habitat use in relation to shipping lanes. The grid raster was populated with values by overlaying grid cell centroids on the interpolated oceanographic and bathymetric layers to extract covariate data on temperature, salinity, fluorescence and depth. In addition, we calculated distances to important features previously described $(200 \mathrm{~m}$ isobath, mainland, Farallon Islands and the center of Cordell Bank) for each grid cell centroid. Monthly regional climate indices were incorporated on a cruise-by-cruise basis and detection bias variables were populated using the most frequently recorded values during data cruises.

Maps indicating the areas with high predicted detection rates (high use) of humpback whales were created by averaging the predictions across years by month and across all months (i.e. for June, July, September and October, as well as all months combined), standardized, and then displayed using percent rank. Note while we retained sightings from May cruises to assist in the model fitting, we did not model May distributions separately due to few detections in that month. Graphs were produced to demonstrate the influence of individual significant predictor variables on humpback whale counts in final models while controlling for the effects of all other variables. In addition, we created a difference map to show where predictions of the surface + mid- 
water and the surface-only model differ across the study area.

Previous and current San Francisco Bay shipping lane layouts were compared with the final humpback whale prediction map, averaged over all months and years, to determine areas of overlap. We determined the maximum footprint of vessel traffic in the previous shipping lane layout using AIS data collected for 2009 from cargo and tanker vessels (Fig. 4). We estimated the likely footprint of vessel traffic in the current shipping lane layout using the proposed lanes paired with the vessel traffic patterns from the previous shipping lanes. We then measured the overlap between both vessel traffic layout footprints within the GFNMS and CBNMS area to compare how adjusting shipping lanes changed between highly used whale habitat and industrial shipping. We did so by measuring each overlapping footprint with the top $2,4,6,8,10$ and $20 \%$ of highly used modeled humpback whale habitat.

\section{RESULTS}

\section{Predictor variables}

The significant variables associated with humpback whale distribution in the GFNMS and CBNMS include surface temperature, surface

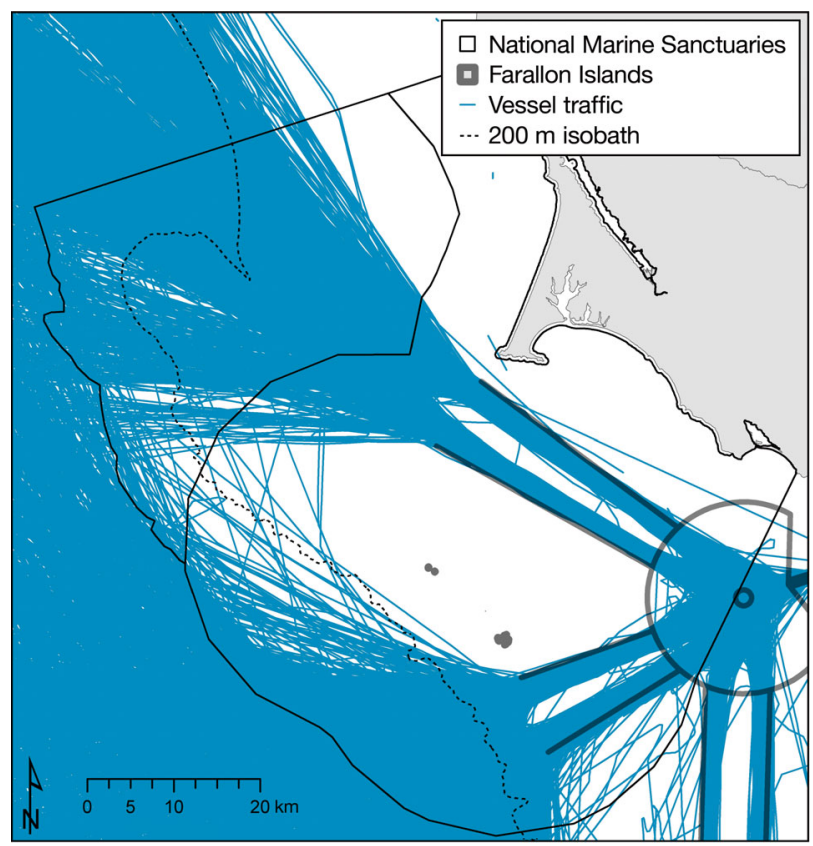

Fig. 4. Vessel traffic data from the Automatic Identification System (AIS) for cargo and tanker ships in 2009. Precautionary area and inbound/outbound lanes as in Fig. 2 salinity, surface fluorescence, mid-water temperature, depth, distance to the $200 \mathrm{~m}$ isobath, UI and NPGO (Table 2). Surface fluorescence was significant in the initial model (without detectability variables) but not in the final model; the variable was retained, however, on the basis of the AIC (see 'Materials and methods'). No significant collinearity was found between covariates as demonstrated by the VIF results (surface + midwater $=2.22$, surface-only $=1.44)$ (Zuur et al. 2010). Cross-validation results show that both models were significant with $\mathrm{p}<0.0001$; however, the surface + mid-water model demonstrated significantly better fit than the surface-only model $(\mathrm{LRS}=8.74, \mathrm{df}=2, \mathrm{p}=0.012)$ (Table 2; Tables S1 and S2 in the Supplement at www.int-res.com/ articles/suppl/n026p039_supp.pdf) We report on the standard error of predictions for each model as follows: for the surface-only model, mean predicted $=0.3249$; mean standard error of the prediction $=0.4466, \mathrm{CV}=1.374 ;$ for the surface + mid-water model, mean predicted $=0.3200$; mean standard error of the prediction $=0.4401, \mathrm{CV}=$ 1.060 (Table S3 in the Supplement). Graphs were produced to assess the influence of fluorescence, temperature, salinity, depth, distance to the $200 \mathrm{~m}$ isobaths and upwelling on humpback whale counts for both models. The surface + midwater model is the preferred model of the 2 (i.e. statistically significantly better fit) and the one we refer to throughout our subsequent discussion (Figs. 5 \& 6). Graphs for habitat variables in the surface-only model can be found in Fig. S1 in the Supplement.

\section{Local trends}

Whale encounter rates varied greatly between years, with low abundances from 2004 to 2009, during which whale encounters never exceeded 0.085 whales $\mathrm{km}^{-1}$, and a period of high abundance in 2010-2011 with the encounter rates ranging from 0.004 to 0.279 whales $\mathrm{km}^{-1}$. In the preferred surface + mid-water model, the effect of year (as a categorical variable) on whale counts was significant (LRS = 39.02, df =7, p < 0.0001; Table 2). Whale encounter rates also varied greatly between months, with the lowest rates in the spring and the highest in the summer and fall (Fig. 7). In the surface + mid-water model, the effect of month (as a quadratic variable) on whale counts was significant (LRS $=83.85$, $\mathrm{df}=2$, $\mathrm{p}<0.0001$; Table 2). 


\section{Surface habitat associations}

The final model showed that the highest humpback whale counts were associated with a sea surface salinity of $\sim 34 \mathrm{psu}$, sea surface temperatures of $12-14^{\circ} \mathrm{C}$ and fluorescence values of $15-30 \mathrm{mg} \mathrm{m}^{-3}$. Humpback whale counts were also significantly associated with shallow depths within proximity to the shelf break, as indicated by their close distance to the $200 \mathrm{~m}$ isobath. Regional climate indices showed an increase in the number of whales seen during periods of high upwelling and a negative association with the NPGO. Note that these patterns were observed in a model that controlled for year effects

Table 2. Results of the final surface + mid-water model including all retained habitat and detection variables, with model fitting, Vuong tests, validation and comparison statistics $(n=2071)$. Habitat variables significant in the initial model were retained in the final models following criteria given in 'Materials and methods'. The complete statistical output for the surfaceonly model is shown in Table S1 in the Supplement at www.int-res.com/articles/suppl/n026p039_supp.pdf. Both models included Year as a categorical variable and Month as a quadratic variable. Quadratic terms are noted with nummeral 2, e.g. Month ${ }^{2}$ as month2. LR: likelihood ratio; LRS: likelihood ratio test statistic; zinb: zero-inflated negativ binomial regression; huwhcnt: humpback whale count

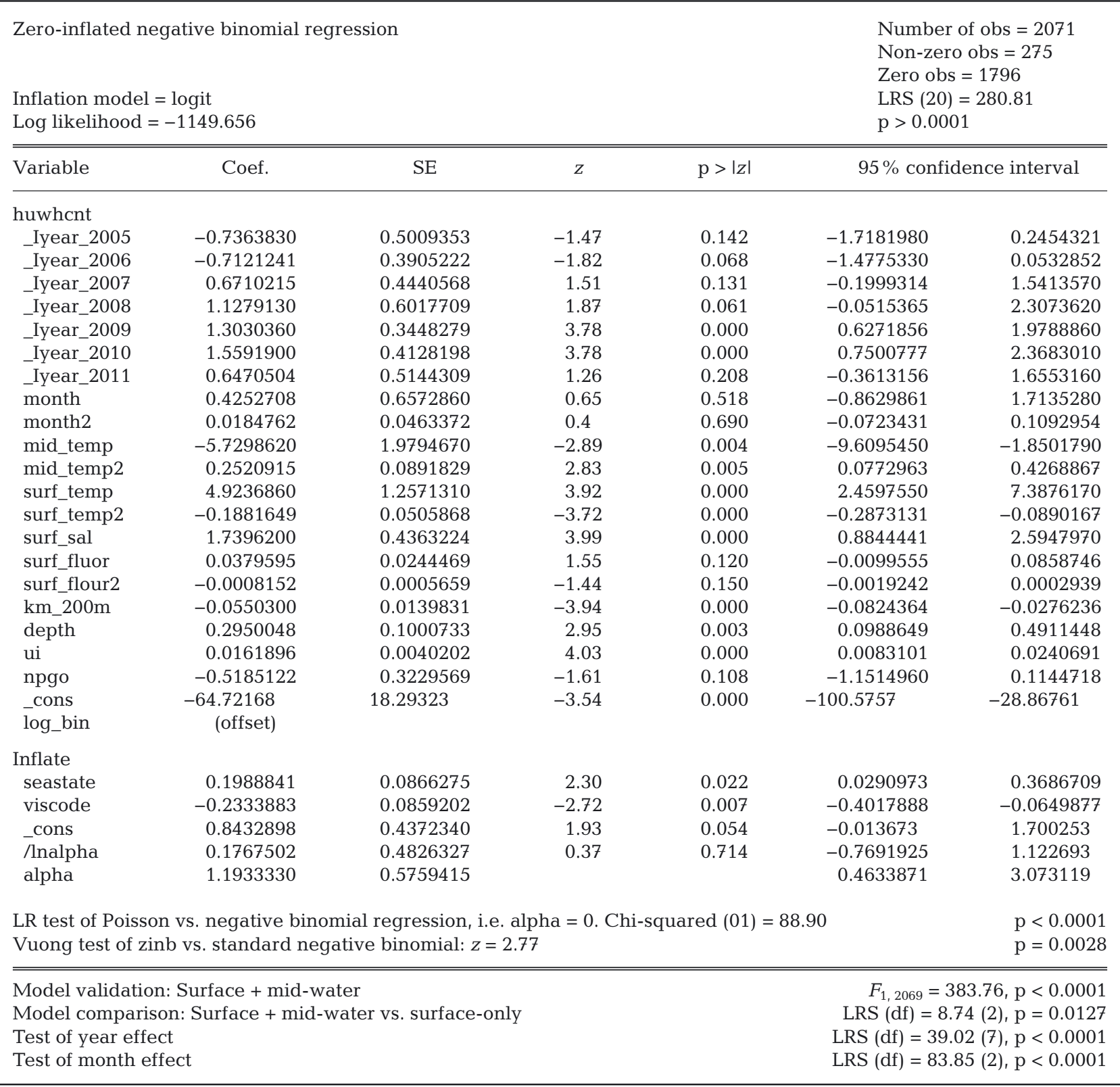



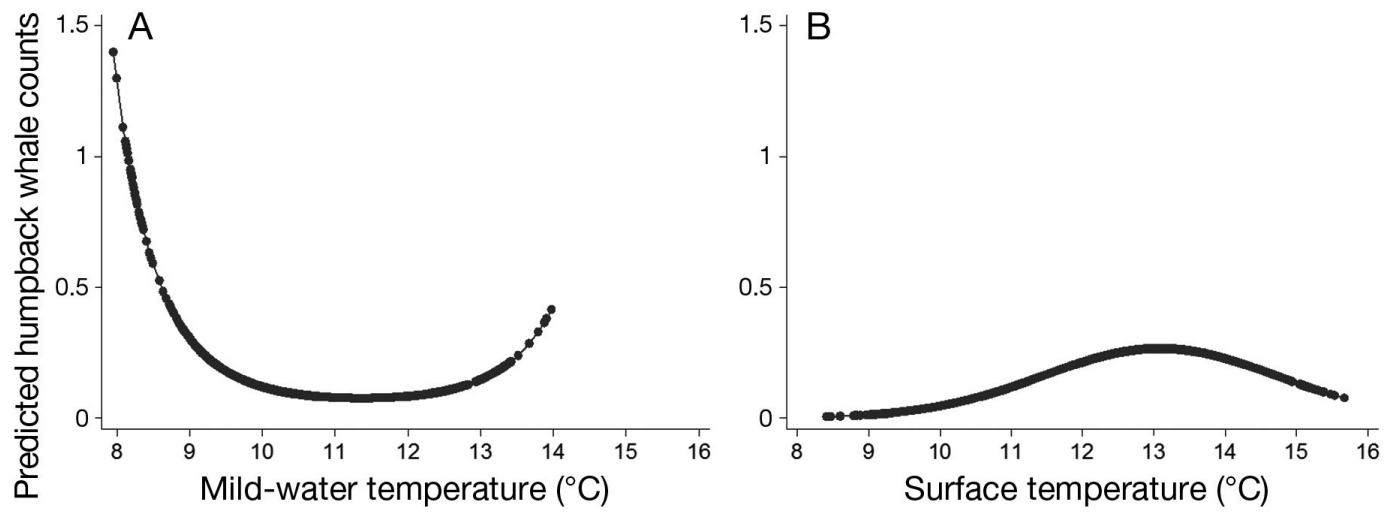

Fig. 5. The predicted relationships between humpback whale counts and temperature in the surface + mid-water model for (A) mid-water and (B) surface temperature. The relationship is shown for each variable, adjusting for the effects of all other variables in the model (see Table 2)
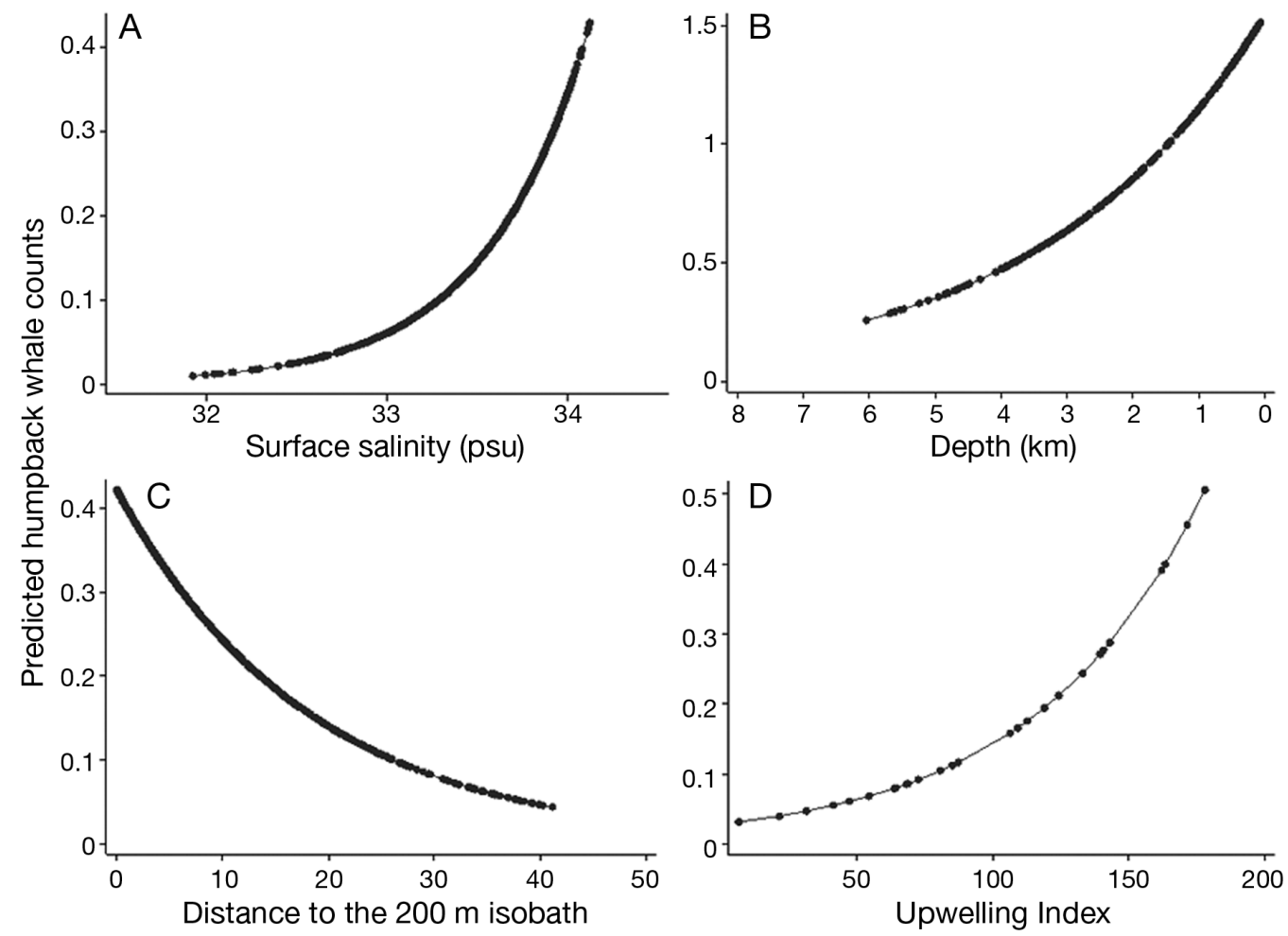

Fig. 6. Predicted relationships between humpback whale counts and oceanographic variables in the surface + mid-water model: (A) surface salinity, (B) depth, (C) distance to the $200 \mathrm{~m}$ isobath and (D) the upwelling index. The relationship is shown for each variable, adjusting for the effects of all other variables in the model (see Table 2)

(as a categorical variable) and the effect of month (as a quadratic).

\section{Mid-water habitat associations}

In addition to the above variables, the surface + mid-water model included mid-water temperature, which indicated that whales were positively associated with temperatures cooler than $\sim 9.5^{\circ} \mathrm{C}$ at some locations at depth, and warmer than $13.5^{\circ} \mathrm{C}$ at other locations. Colder mid-waters corresponded to similar cold surface temperatures (mean $=9.9^{\circ} \mathrm{C}$, range $=8.4-12.4^{\circ} \mathrm{C}$ ) and high surface salinity (mean $=33.70 \mathrm{psu}$, range $=32.57-34.13 \mathrm{psu}$ ), which is typical of aged upwelled waters; upwelled water that has 


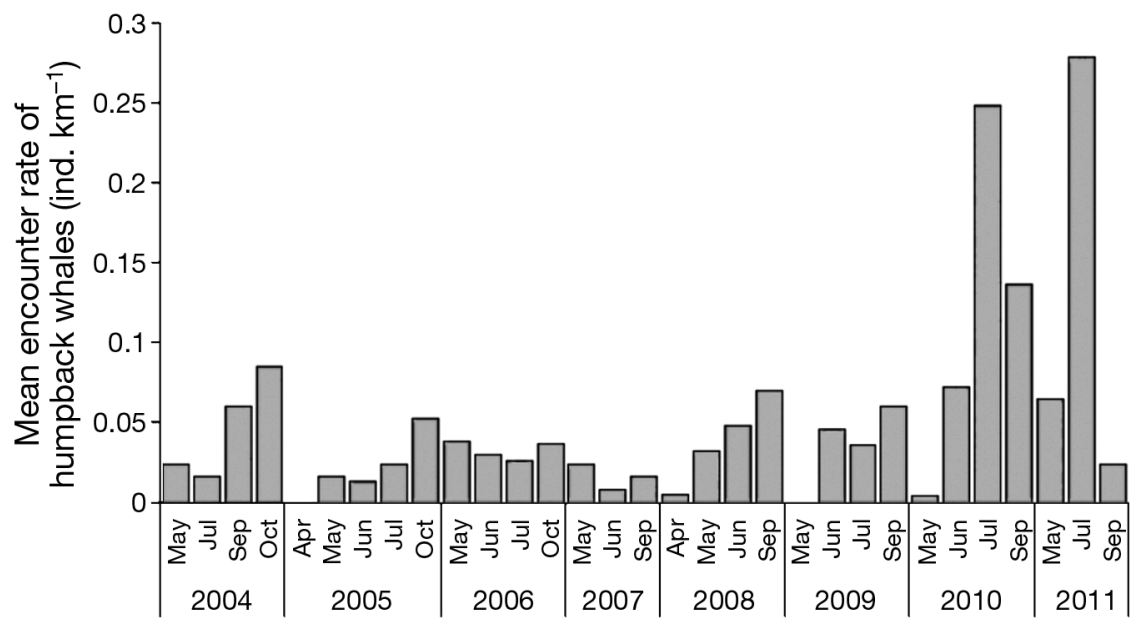

Fig. 7. Humpback whale encounter rates in the Cordell Bank and Gulf of the Farallones National Marine Sanctuaries. In April 2005 and May 2009, there were zero detections

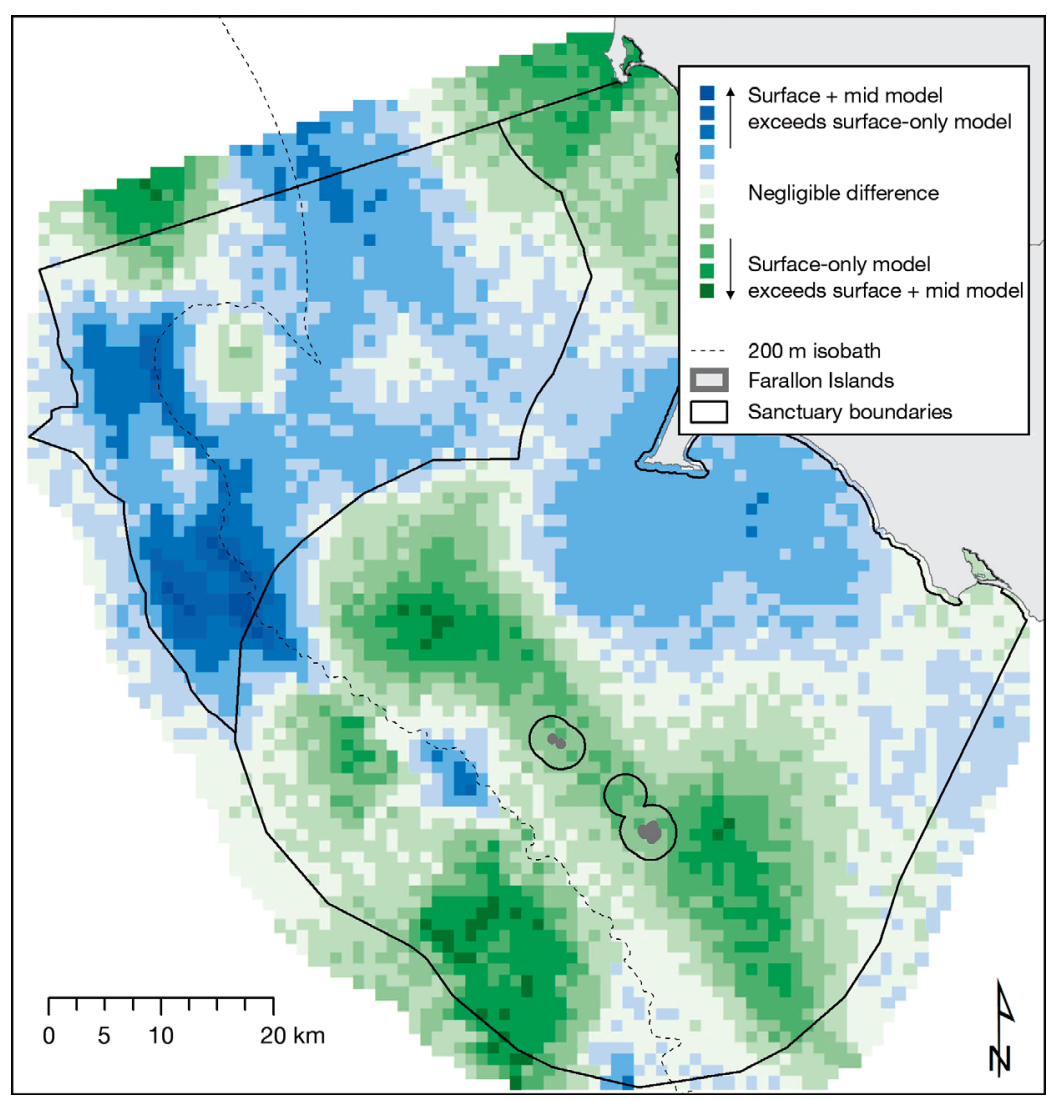

Fig. 8. Spatial differences in predicted abundance between the surface + midwater and surface-only models. Blue areas show where predicted abundance in the surface + mid-water model exceeds predicted abundance in the surfaceonly model; the opposite is shown in green. Darker shades reflect greater differences in prediction between the 2 models for humpback whale habitat in the Cordell Bank and Gulf of the Farallones National Marine Sanctuaries (see Fig. 1 for the locations of the sanctuaries) been on the surface for $5-6 \mathrm{~d}$ is referred to as 'aged upwelled' water (García-Reyes \& Largier 2012). Warmer mid-waters corresponded to warmer surface waters $\left(\right.$ mean $=14.9^{\circ} \mathrm{C}$, range $=14.8-15.2^{\circ} \mathrm{C}$ ) and lower surface salinity $($ mean $=33.27 \mathrm{psu}$, range $=$ 32.95-33.45 psu), which is more typical of offshore waters. The map showing the spatial difference in predicted habitat between the 2 models indicated that the surface-only model exceeded whale habitat predictions in areas north, south and west of the Farallon Islands, relative to the surface + mid-water model. Moreover, the surface-only model under-predicted whale habitat use in areas along the shelf break west and southwest of Cordell Bank in comparison to the surface + mid-water model (Fig. 8).

\section{Detection bias}

Controlling for detection variables significantly improved the surface + mid-water model and the surface-only model, as indicated by the Vuong statistic ( $p=0.0028)$. From all candidate detection variables tested, only sea state and visibility significantly accounted for zero inflation in the models (Table 2). More whales were seen when conditions provided improved visibility and higher sea states.

\section{Predictive maps}

Final prediction maps showing humpback whale modeled habitat use were created for the surface + mid-water model, by month (Fig. 9) and for all 4 months combined (Fig. 10). A visual comparison of the monthly maps shows that in June, areas highly used by humpback whales occur northeast of Cordell Bank and southwest of the Farallon Islands; in July, these areas expand northwards along the shelf break; in September, modeled habitat is found 

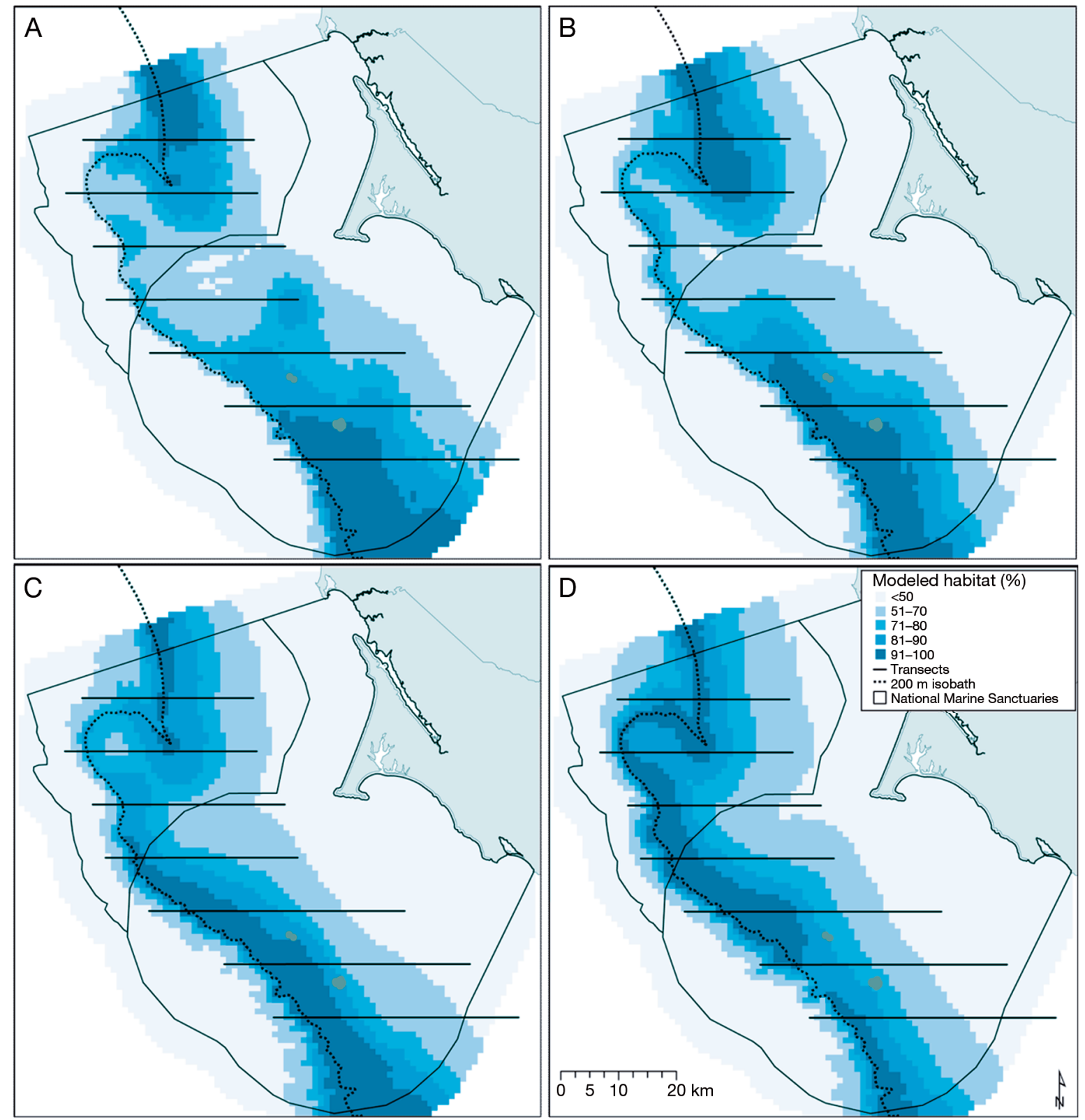

Fig. 9. Final prediction maps showing highly used modeled habitat for (A) June, (B) July, (C) September and (D) October. Sanctuaries and transects as in Fig. 1

along most of the shelf break within our study area; and in October, these areas shift north with reduced abundance southwest of the Farallon Islands and increased abundance to the north. The map of all months combined shows similar patterns, with the most common locations of recurrent use occurring along and inshore from the shelf break, particularly north of Cordell Bank and southwest of the Farallon Islands (Fig. 10). Final prediction maps showing yearly humpback whale modeled habitat use are given in Fig. S2 in the Supplement.

\section{San Francisco Bay vessel traffic}

The footprint of the previous shipping lane layout contains $2686 \mathrm{~km}^{2}$ of the total area of the CBNMS and GFNMS combined (Fig. 11A), while the footprint of the current shipping lanes encompasses only 994 $\mathrm{km}^{2}$ (Fig. 11B), resulting in a decrease in the vessel traffic footprint by $69 \%$. The differences in overlap between previous and current shipping lanes and the top $\leq 20 \%$ of our modeled humpback whale foraging habitat indicated a reduction in overlap ranging from 64.7 to $75.9 \%$ (Table 3 ). 


\section{DISCUSSION}

\section{Local trends}

Whale sightings varied over time, with low numbers of whale encounters from 2004 to 2009 and increased sightings in 2010 and 2011 (Fig. 7). This pattern is broadly supported by other studies such as Becker et

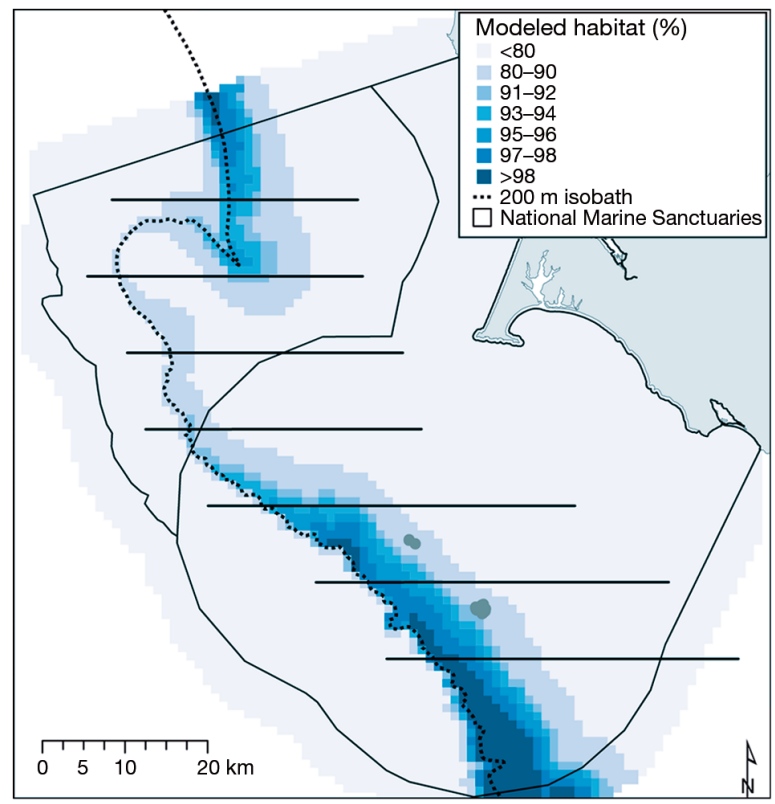

Fig. 10. Highly used humpback whale habitat model results for all months combined. Sanctuaries and transects as in Fig. 1 al. (2012), and may be related to overall productivity and prey availability patterns in the region. The oceanography in central California showed a similar pattern, with overall low primary productivity from 2005 to 2008 when compared with the northern and southern California Current System (Bjorkstedt et al. 2010, 2011). Highly anomalous ocean conditions were observed in the summer of 2005, with late upwelling and high surface temperatures resulting in extremely low productivity in the area (Brodeur et al. 2006, Schwing et al. 2006, Sydeman et al. 2006). Krill abundance was particularly low from 2004 to 2006, which was attributed to decreased upwelling in the California Current (Jahncke et al. 2008, Santora et al. 2011). From mid-2007 to early 2009, cool conditions associated with La Niña were present but regional variability was dominant and low productivity was found in the northern California Current region (Bjorkstedt et al. 2010). Krill are the main prey item for humpback whales in our study area, but surveys revealed some prey-switching in humpback whales from krill to fish for the years 2006 and 2007, corresponding to periods of lower productivity (J. Jahncke, pers. obs.). The statistical model revealed that by spring/summer 2009, whale detections were significantly higher compared with the 2004-2007 period and remained high through 2011. Krill abundance estimates from our study region followed a similar pattern, with higher biomass observed in the 2009-2011 period (J. Jahncke, pers. obs.).

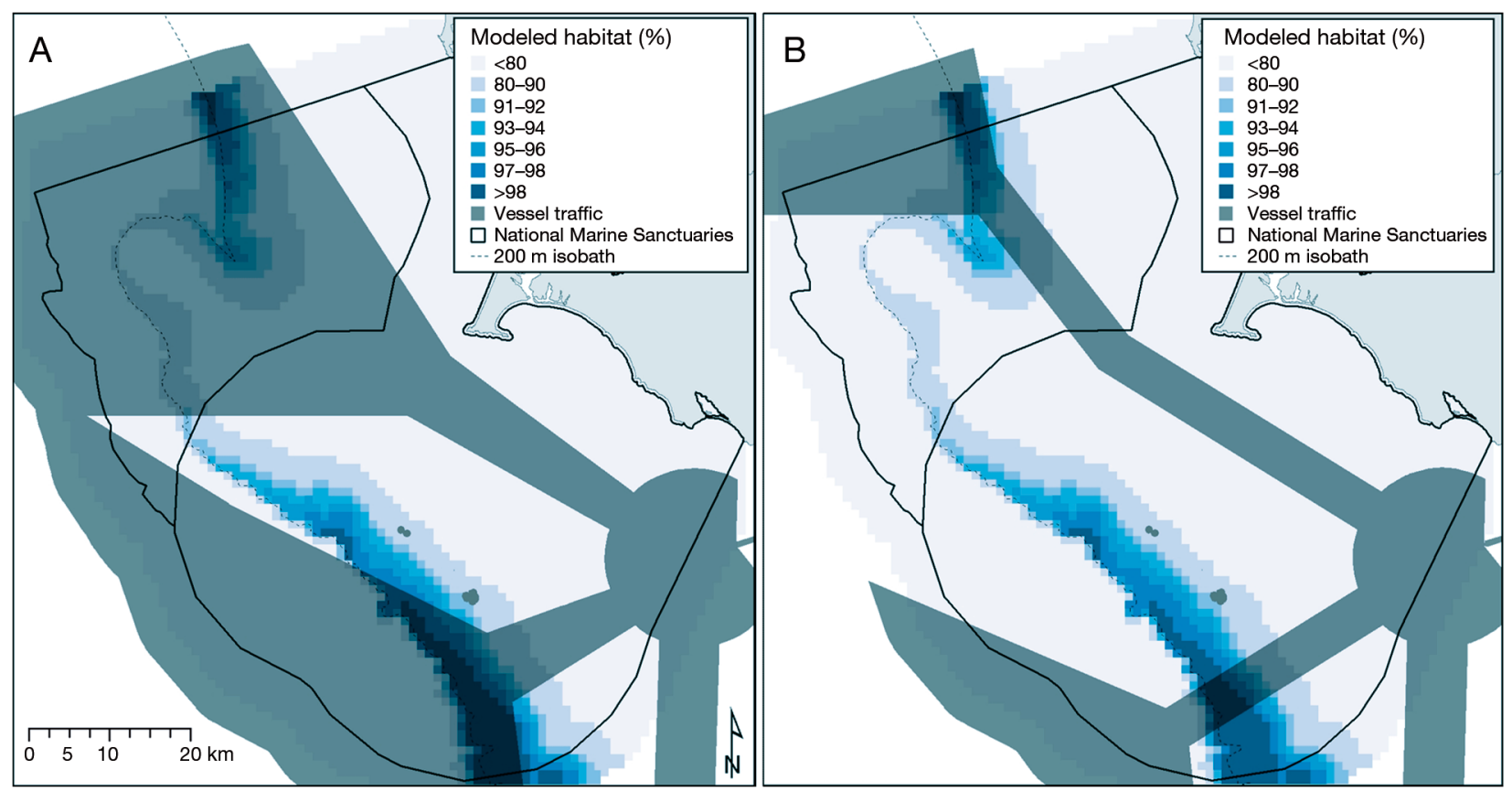

Fig. 11. (A) Previous and (B) current San Francisco Bay shipping lanes (gray shading) overlaid on highly used humpback whale habitat model results, averaged across all months 
Table 3. Changes in overlap between humpback whale modeled habitat (areas of high use) and the footprints of previous and current shipping lanes

\begin{tabular}{|lcccc|}
\hline \multirow{2}{*}{$\begin{array}{c}\text { Modeled } \\
\text { habitat (\%) }\end{array}$} & $\begin{array}{c}\text { Modeled } \\
\text { habitat }\left(\mathrm{km}^{2}\right)\end{array}$ & $\begin{array}{c}\text { Previous } \\
\text { lanes }\left(\mathrm{km}^{2}\right)\end{array}$ & $\begin{array}{c}\text { Current } \\
\text { lanes }\left(\mathrm{km}^{2}\right)\end{array}$ & $\begin{array}{c}\text { Change } \\
(\%)\end{array}$ \\
\hline 2 & 97 & 83 & 20 & -75.9 \\
4 & 190 & 144 & 43 & -70.1 \\
6 & 287 & 193 & 67 & -65.3 \\
8 & 392 & 248 & 90 & -63.2 \\
10 & 555 & 296 & 109 & -63.2 \\
20 & 1016 & 609 & 215 & -64.7 \\
\hline
\end{tabular}

\section{Surface habitat associations}

Patterns of humpback whale sightings revealed habitat associations with key oceanographic variables. There was a strong association between whale sightings and the upwelling index. Such associations with water properties and productivity in humpback whales and other whale and dolphin species have been found off Monterey Bay (Croll et al. 2005), Heceta Bank and Cape Blanco off the Oregon coast (Tynan et al. 2005), the continental shelf of British Columbia (Gregr \& Trites 2001, Dalla-Rosa et al. 2012), and along the Aleutian Islands (Sinclair et al. 2005), among others. The highest numbers of whale sightings were associated with aged upwelled waters (García-Reyes \& Largier 2012) as indicated by high sea surface salinity ( 34 psu), warmer relative sea surface temperatures of $12-14^{\circ} \mathrm{C}$ and high fluorescence values of $15-30 \mathrm{mg} \mathrm{m}^{-3}$.

\section{Mid-water habitat associations}

Humpback whale sightings showed additional linkages to mid-water properties, which are often not considered in habitat modeling. We found a sharp contrast between temperatures of water masses highly used by humpback whales at depth. This contrast was manifested in differences in humpback habitat use of either aged upwelled or offshore waters. Fontana (2013) showed that aged upwelled waters are predominantly found in the northern half of the study area (transects 1 to 4), while a combination of offshore, upwelled and bay water masses are found in the southern half of the study area converging at the Farallon Islands (transects 5 to 7 ). Offshore and San Francisco Bay water masses have lower salinity and higher temperature (Wing et al. 1998, Hill \& Wheeler 2002), which is reflected in our results. Waters converging off the Farallones as well as waters over Cordell Bank have increased primary productivity (Hurst \& Bruland 2008, Halle \& Largier 2011). Therefore, adding mid-water properties improved the predictive ability of the model likely because they are a better proxy for prey availability than the surface waters alone. This is supported by research that has established that zooplankton are more associated with oceanography within the upper $50 \mathrm{~m}$ in the water column (Hopkins 1982). Krill migrate to above $40 \mathrm{~m}$ at night and are below 50-200 m during the day (Croxall et al. 1985). Daytime depth for krill has been seen to be deeper at the shelf break ( 150-200 m) than on the shelf $(\sim 100-150 \mathrm{~m})$ and correspond to temperatures of $6-7^{\circ} \mathrm{C}$ and a salinity of 33.75-34 psu (Simard \& Mackas 1989). In Monterey Bay, California, Croll et al. (2005) found krill between depths of 80-180 m. Adding mid-water temperature to the model reflected these oceanographic properties related to prey availability in the water column.

The sharp contrast between densities (due to differences in temperature and salinity) of water masses used by humpback whales may also point to the utilization of fronts. Fronts are regions of enhanced horizontal gradients in temperature and salinity which can lead to increased productivity (Dalla Rosa et al. 2012). Humpback whales have been known to use fronts (Tynan et al. 2005), whereby the whales appeared to be associated with the inside edge of the coastal upwelling front of the northern California Current System. The vertical flux of nutrients occurring at fronts can effectively concentrate phytoplankton and zooplankton, which attracts krill, fish and their predators (Hunt et al. 1998, Brodeur et al. 2000, Pinchuk et al. 2008). Associations with fronts have been found in other studies on humpback whales as well as other cetaceans (Croll et al. 1998, Yen et al. 2004, Tynan et al. 2005)

Humpback whale associations with bathymetric variables revealed that, after controlling for hydrographic and other variables, more whales used the waters near the edge of the continental shelf. This is supported by other studies that found similar associations with bathymetric features, particularly shelf breaks and slopes, for humpback whales and other cetaceans (Gregr \& Trites 2001, Yen et al. 2004, Keiper et al. 2005, Tynan et al. 2005, Friedlaender et al. 2006, Becker et al. 2012, Dalla Rosa et al. 2012). The basis for this relationship is that krill are often concentrated at discrete depths in the water column 
and are associated with the topographic shelf break (Brodeur et al. 2000, Croll et al. 2005, Tynan et al. 2005, Pinchuk et al. 2008, Dalla Rosa et al. 2012).

\section{Detection bias}

We found evidence of 2 weather-related biases in detection, sea state and visibility, which appeared counter-intuitive. Generally it is expected that more whales can be seen when the ocean is calm and visibility is clear. However, in our analysis we found a significant tendency to observe more whales in rough ocean conditions and poor visibility. This is likely due to fog conditions; in our study region, fog can develop and settle more effectively on the surface during calm weather, resulting in poor visibility (Kora in et al. 2005). In rough weather, the fog quickly dissipates, facilitating the detection of large whales.

\section{Predictive maps}

These results highlight the importance of fine-scale modeling with in situ data to be able to identify highuse humpback whale habitat, which is useful from a management perspective. This study addresses finescale patterns of distribution that other studies could not, given their coarser sampling distributions. Furthermore, we determined that mid-water properties significantly improved predictions relative to models that only use surface variables. Visualizing the spatial differences in highly used humpback whale habitat predicted by models shows that using only surface water variables would have led to omission of key habitat in the vicinity of Cordell Bank (Fig. 8). Other regional-scale habitat modeling studies support our findings and have also found that Cordell Bank and the Farallon Islands are highly used habitat for several species of cetaceans (Becker et al. 2012, Forney et al. 2012). Our research builds on the modeling results of these studies by providing fine-scale site-specific details in the CBNMS and GFNMS.

\section{San Francisco Bay vessel traffic}

Although our results revealed that the current shipping lane layout reduced the area of the vessel traffic footprint within the sanctuaries by $69 \%$ and reduced overlap with areas modeled as highly used by humpback whales by $76 \%$ (when considering the top 2 to $4 \%$ of highest use areas), the resulting changes in ship-strike risk cannot be determined without a more explicit exploration of the effects of concentrating shipping traffic. In particular, humpback whales do not use the sanctuaries uniformly, and highly used areas northeast of Cordell Bank and south of the Farallon Islands still overlap with the current narrower shipping lanes. Additionally, using a vessel footprint does not account for several important aspects of ship-strike risk, including frequency, speed, size and density patterns within the shipping lanes and variability between lanes. Reducing the area of a vessel footprint to decrease overlap with habitat areas could have negative consequences if the result is a disproportionate increase in density of ships traveling through the lane. For example, currently there is increased risk in the western lane as it experiences more vessel traffic than the northern or southern approaches (Joint Working Group on Vessel Strikes and Acoustic Impacts 2012). There is ongoing research to process AIS data within the sanctuaries to analyze vessel density patterns nocturnally, seasonally and inter-annually, and under changing management regimes. Additional measures of protection for whales may be needed in high-use areas where elevated co-occurrence between baleen whales and ships still remains, particularly north of Cordell Bank near the outer end of the northern shipping lane (Fig. 11B), which may now be subject to a higher density of ship traffic. It is also important to note that this study modeled habitat for one species of whale; other species should also be considered when evaluating vessel traffic and shipping lanes in the sanctuaries, as in Redfern et al. (2013).

This research will assist the CBNMS and GFNMS to make informed management recommendations to regulatory authorities (USCG and International Maritime Association) about shipping lane delineation and the level of protection necessary for humpback whales in the sanctuaries (Table 3). Our results support Sanctuary Advisory Council recommendations involving modification of shipping lanes to avoid areas of whale concentrations, and may influence decisions for further adjustments to the lanes, especially in the northern approach lane near Cordell Bank. With the previous shipping lanes, there was little area within the sanctuaries that was restricted from traveling tankers and cargo ships. Further recommendations from the Sanctuary Advisory Councils include new strategies to reduce risk such as Dynamic Management Areas (DMAs) (Joint Working Group on Vessel Strikes and Acoustic Impacts 2012). DMAs could be employed in certain areas and times 
of whale concentrations as a more flexible management option. The development of a real-time whale sighting and monitoring network could inform the designation of DMAs and advise vessels to reduce speed or choose alternate shipping lanes. This approach can be adopted by other National Marine Sanctuaries and marine protected areas.

\section{CONCLUSIONS}

Cetacean habitat modeling can be a powerful technique for predicting high-use habitat and understanding the ecological processes or drivers of habitat selection (Redfern et al. 2006). Our work has furthered cetacean modeling research through advanced modeling approaches that include multidepth, in situ data that produce predictive habitat models that can be directly applied to management actions. Our research exemplifies how habitat models can be important tools for mitigating anthropogenic threats, and demonstrates the importance of spatial management strategies along coasts with busy ports to reduce the threat of ship strikes. This research has contributed towards understanding the temporal and spatial distribution of humpback whales along the California coast and forms the basis for future habitat modeling and AIS data analysis within local National Marine Sanctuaries. This approach can be applied elsewhere to model cetacean habitat use, identify priority areas for conservation, and highlight potential areas of conflict with human activities to inform managers of coastal and marine protected areas.

Acknowledgements. We thank the many partners and contributors whose support has made this initiative and paper possible. This work was supported in part by the Applied California Current Ecosystem Studies (ACCESS, www.access oceans.org) Partnership, an ongoing collaboration between Point Blue Conservation Science and the Cordell Bank and Gulf of the Farallones National Marine Sanctuaries to support marine wildlife conservation and healthy ecosystems in northern and central California. We thank Seth Hiatt from the Institute of GIScience at San Francisco State University for his development of the custom Python scripting code. We thank Michael Thompson from Stellwagen Bank National Marine Sanctuary for providing the USCG's National AIS Program data. Jessica Redfern, Southwest Fisheries Science Center, and John Calambokidis, Cascadia Research, were invaluable in the review of the manuscript. We also thank Maria Brown, Lisa Etherington and Dan Howard for their support, as well as Jan Roletto, Kaitlin Graiff and volunteers from the Gulf of the Farallones National Marine Sanctuary for coordinating and facilitating the ACCESS cruises. We thank the Boring Family Foundation, Elinor Paterson Baker
Trust, Faucett Catalyst Fund, Hellman Family Foundation, Moore Family Foundation, National Fish and Wildlife Foundation, Resources Legacy Fund, Wendy P. McCaw Foundation and the many Point Blue donors who have helped fund ACCESS work over the years. This is Point Blue Conservation Science contribution number 1907.

\section{LITERATURE CITED}

Bakun A (1973) Coastal upwelling indices, west coast of North America, 1946-71. US Department of Commerce, NOAA Tech Rep NMS SSRF-671

Barlow J, Ferguson MC, Becker EA, Redfern JV and others (2009) Predictive modeling of marine mammal density from existing survey data and model validation using upcoming surveys. SERDP Project SI-1391. National Oceanic and Atmospheric Administration, Washington, DC

Barlow J, Calambokidis J, Falcone EA, Baker CS and others (2011) Humpback whale abundance in the North Pacific estimated by photographic capture-recapture with bias correction from simulation studies. Mar Mamm Sci 27: 793-818

Barry SC, Welsh AH (2002) Generalized additive modeling and zero inflated count data. Ecol Model 157:179-188

Baumgartner MF (2003) Comparisons of Calanus finmarchicus fifth copepod abundance estimates from nets and an optical plankton counter. J Plankton Res 25:855-868

Baumgartner MF, Fratantoni DM (2008) Diel periodicity in both sei whale vocalization rates and the vertical migration of their copepod prey observed from ocean gliders. Limnol Oceanogr 53:2197-2209

Beal DJ (2005) Information criteria methods in SAS for multiple linear regression models. Science Applications International Corporation, Oak Ridge, TN

Becker EA, Forney KA, Ferguson MC, Barlow J, Redfern JV (2012) Predictive modeling of cetacean densities in the California Current Ecosystem based on summer/fall ship surveys in 1991-2008. NOAA-TM-NMFS-SWFSC-499

Beekmans BWPM, Forcada J, Murphy EJ, De Baar HJW, Bathmann UV, Fleming AH (2010) Generalised additive models to investigate environmental drivers of Antarctic Minke whale (Balaenoptera bonaerensis) spatial density in austral summer. J Cetacean Res Manag 11:115-129

Bello-Pineda J, Hernández-Stefanoni JL (2007) Comparing the performance of two spatial interpolation methods for creating a digital bathymetric model of the Yucatan submerged platform. PANAMJAS 2:247-254

Benson SR, Croll DA, Marinovic BB, Chavez FP, Harvey JT (2002) Changes in the cetacean assemblage of a coastal upwelling ecosystem during El Niño 1997-98 and La Niña 1999. Prog Oceanogr 54:279-291

Berman-Kowalewski M, Gulland FMD, Wilkin S, Calambokidis J and others (2010) Association between blue whale (Balaenoptera musculus) mortality and ship strikes along the California coast. Aquat Mamm 36:59-66

Bjorkstedt EP, Goericke R, McClatchie S, Weber E and others (2010) State of the California current 2009-2010: regional variation persists through transition from La Niña to El Niño (and back?). Cal COFI Rep 51:39-69

Bjorkstedt EP, Goericke R, McClatchie S, Weber E and others (2011) State of the California current 2009-2010: regionally variable responses to a strong (but fleeting?) La Niña. Cal COFI Rep 52:36-68 
Brodeur RD, Wilson MT, Ciannelli L (2000) Spatial and temporal variability in feeding and condition of age-0 walleye polluck (Theragra chalcogramma) in frontal regions of the Bering Sea. ICES J Mar Sci 57:256-264

> Brodeur RD, Ralston S, Emmett R, Trudel M, Auth T, Phillips A (2006) Anomalous pelagic nekton abundance, distribution, and apparent recruitment in the northern California Current in 2004 and 2005. Geophys Res Lett 33: L22S08, doi:10.1029/2006GL026614

> Calambokidis J, Barlow J (2004) Abundance of blue and humpback whales in the eastern north Pacific estimated by capture-recapture and line-transect methods. Mar Mamm Sci 20:63-85

Calambokidis J, Steiger GH, Straley JM, Herman LM and others (2001) Movements and population structure of humpback whales in the North Pacific. Mar Mamm Sci 17:769-794

Calambokidis, J, Falcone EA, Quinn TJ, Burdin AM and others (2008) SPLASH: Structure of populations, levels of abundance and status of humpback whales in the North Pacific. Final Report for Contract AB133F-03-RP-00078. US Dept of Commerce, Washington, DC

California Department of Fish and Wildlife (2012) Marine Region GIS Unit: Downloads. Available at www.dfg.ca. gov/marine/gis/downloads.asp (accessed 15 October 2012)

Carretta JV, Oleson E, Weller DW, Lang AR and others (2013) US Pacific Marine Mammal Stock Assessments: 2012. NOAA-TM-NMFS-SWFSC-504

> Clapham PJ, Young SB, Brownell RL Jr (1999) Baleen whales: conservation issues and the status of the most endangered populations. Mammal Rev 29:37-62

Claridge DE (2006) Fine-scale distribution and habitat selection of beaked whales. MS thesis, Florida Institute of Technology, Melbourne, FL

Conn PB, Silber GK (2013) Vessel speed restrictions reduce risk of collision-related mortality for North Atlantic right whales. Ecosphere 4:43, doi:10.189/ES13-00004.1

Croll DA, Tershy BR, Hewitt R, Demer D and others (1998) An integrated approach to the foraging ecology of marine birds and mammals. Deep-Sea Res II 45:1353-1371

Croll DA, Marinovic B, Benson S, Chavez FP, Black N, Ternullo R, Tershy BR (2005) From wind to whales: trophic links in a coastal upwelling system. Mar Ecol Prog Ser 289:117-130

> Croxall JP, Everson I, Kooyman GL, Ricketts C, Davis RW (1985) Fur seal diving behavior in relation to krill vertical distribution. J Anim Ecol 54:1-8

Cullen JJ (1982) The deep chlorophyll maximum: comparing vertical profiles of chlorophyll a. Can J Fish Aquat Sci 39:791-803

Cunningham RB, Lindenmayer DB (2005) Modeling count data of rare species: some statistical issues. Ecology 86: 1135-1142

> Dalla Rosa L, Ford JKB, Trites AW (2012) Distribution and relative abundance of humpback whales in relation to environmental variables in coastal British Columbia and adjacent waters. Cont Shelf Res 36:89-104

> Di Lorenzo E, Schneider N, Cobb KM, Franks PJS and others (2008) North Pacific Gyre Oscillation links ocean climate and ecosystem change. Geophys Res Lett 35: L08607, doi:10.1029/2007GL032838

Elith J, Leathwick JR (2009) Ecological explanation and prediction across space and time. Annu Rev Ecol Syst 40: 677-697
Embling CB, Gillibrand PA, Gordon J, Shrimpton J, Stevick PT, Hammond PS (2010) Using habitat models to identify suitable sites for marine protected areas for harbor porpoises (Phocoena phocoena). Biol Conserv 143:267-279

> Ferguson MC, Barlow J, Fiedler P, Reilly SB, Gerrodette T (2006) Spatial models of delphinid (family Delphinidae) encounter rate and group size in the eastern tropical Pacific Ocean. Ecol Model 193:645-662

Fontana RE (2013) Physical process and their influence on zooplankton composition and foraging opportunities for seabirds in a strong, persistent upwelling region: Gulf of the Farallones-Cordell Bank (California). PhD dissertation, University of California, Davis, CA

Forney KA, Ferguson MC, Becker EA, Fiedler PC and others (2012) Habitat-based spatial models of cetacean density in the eastern Pacific Ocean. Endang Species Res 16: 113-133

Franklin J (2009) Mapping species distributions: spatial inference and prediction. Cambridge University Press, New York, NY

Friedlaender AS, Halpin PN, Qian SS, Lawson GL, Wiebe PH, Thiele D, Read AJ (2006) Whale distribution in relation to prey abundance and oceanographic processes in shelf waters of the western Antarctic Peninsula. Mar Ecol Prog Ser 317:297-310

García-Reyes M, Largier JL (2012) Seasonality of coastal upwelling off central and northern California: New insights, including temporal and spatial variability. J Geophys Res 117:C03028, doi:10.1029/2011JC007629

Goldbogen JA, Calambokidis J, Croll D, Harvey J and others (2008) Foraging behavior of humpback whales: kinematic and respiratory patterns suggest a high cost for a lunge. J Exp Biol 211:3712-3719

Gregr EJ, Trites AW (2001) Predictions of critical habitat for five whale species in the waters of coastal British Columbia. Can J Fish Aquat Sci 58:1265-1285

Gregr EJ, Baumgartner MF, Laidre KL, Palacios DM (2013) Marine mammal habitat models come of age: the emergence of ecological and management relevance. Endang Species Res 22:205-212

> Guisan A, Thuiller W (2005) Predicting species distribution: offering more than simple habitat models. Ecol Lett 8: 993-1009

Halle CM, Largier JL (2011) Surface circulation downstream of the Point Arena upwelling center. Cont Shelf Res 31: 1260-1272

Hazen EL, Nowacek DP, St. Laurent L, Halpin PN, Moretti DJ (2011) The relationship among oceanography, prey fields, and beaked whale foraging habitat in the Tongue of the Ocean. PLoS ONE 6:e19269

- Hickey BM, Banas NS (2008) Why is the northern end of the California Current System so productive? Oceanography 21:90-107

Hill JK, Wheeler PA (2002) Organic carbon and nitrogen in the northern California current system: comparison of offshore, river plume, and coastally upwelled waters. Prog Oceanogr 53:369-387

> Hirzel AH, Le Lay G (2008) Habitat suitability modeling and niche theory. J Appl Ecol 45:1372-1381

Hopkins TL (1982) The vertical distribution of zooplankton in the eastern Gulf of Mexico. Deep-Sea Res Oceanogr A 29:1069-1083

Hosmer DW Jr, Lemeshow S (2000) Applied Logistic Regression, 2nd edn. Wiley, New York, NY

> Hunt GL Jr, Russel RW, Coyle KO, Weingartner T (1998) 
Comparative foraging ecology of planktivorous auklets in relation to ocean physics and prey availability. Mar Ecol Prog Ser 167:241-259

Hurst MP, Bruland KW (2008) The effect of the San Francisco Bay plume on trace metal and nutrient distributions in the Gulf of the Farallones. Geochim Cosmochim Acta 72:395-411

IUCN (2012) IUCN Red List of Threatened Species. Version 2012.2. Available at www.iucnredlist.org (accessed 2 October 2012)

Jahncke J, Saenz BL, Abraham CL, Rintoul C, Bradley RW, Sydeman WJ (2008) Ecosystem responses to short-term climatic variability in the Gulf of the Farallones, California. Prog Oceanogr 77:182-193

Johnston K, Ver Hoef JM, Krivoruchko K, Lucas N (2001) Using ArcGIS Geostatistical Analyst. ESRI, Redlands, CA

> Johnston DW, Chapla ME, Williams LE, Mattila DK (2007) Identification of humpback whale Megaptera novaeangliae wintering habitat in the Northwestern Hawaiian Islands using spatial habitat modeling. Endang Species Res 3:249-257

Joint Working Group on Vessel Strikes and Acoustic Impacts (2012) Vessel strikes and acoustic impacts. Joint Working Group of Gulf of the Farallones and Cordell Bank National Marine Sanctuaries Advisory Councils, San Francisco, CA

Keiper CA, Ainley DG, Allen SG, Harvey JT (2005) Marine mammal occurrence and ocean climate off central California, 1986 to 1994 and 1997 to 1999. Mar Ecol Prog Ser 289:285-306

Kerosky S, Munger L, Hildebrand J (2008) Cetacean research and conservation: A summary of current efforts and future needs. Scripps Institute of Oceanography, University of California, San Diego, CA

Knowlton AR, Brown MW (2007) Running the gauntlet: right whales and vessel strikes. In: Kraus SD, Rolland RM (eds) The urban whale. Harvard University Press, Cambridge, MA, p 409-435

Knowlton AR, Kraus SD (2001) Mortality and serious injury of northern right whales (Eubalaena glacialis) in the western North Atlantic Ocean. J Cetacean Res Manag 2:193-208

Kohavi R (1995) A study of cross-validation and bootstrap for accuracy estimation and model selection. In: Mellish CS (ed) International Joint Conference on Artificial Intelligence. Morgan Kauffmann Publishers, San Francisco, CA, p 1137-1143

Kora in D, Businger JA, Dorman CE, Lewis JM (2005) Formation, evolution, and dissipation of coastal sea fog. Boundary-Layer Meteorol 117:447-478

Kraus SD, Brown MW, Caswell H, Clark CW and others (2005) North Atlantic right whales in crisis. Science 309: 561-562

Laist DW, Knowlton AR, Mead JG, Collet AS, Podesta M (2001) Collisions between ships and whales. Mar Mamm Sci 17:35-75

Long JS (1997) Regression models for categorical and limited dependent variables. Sage Publications, Thousand Oaks, CA

Mantua NJ, Hare SR, Zhang Y, Wallace JM, Francis RC (1997) A Pacific decadal climate oscillation with impacts on salmon. Bull Am Meteorol Soc 78:1069-1079

McGowan J, Hines E, Howar J, Dransfield A and others (2013) Using seabird habitat modeling to inform marine spatial planning in central California's national marine sanctuaries. PLoS ONE 8:e71406
Michael PE, Hyrenbach KD, Jahncke J (2014) Balancing act: relative influence of static and dynamic features on black-footed albatross habitat use in California National Marine Sanctuaries. Fish Oceanogr 23:18-31

National Marine Fisheries Service (1991) Recovery plan for the humpback whale (Megaptera novaeangliae). National Marine Fisheries Service, Silver Spring, MD, p 105

National Marine Fisheries Service (2010) California Marine Mammal Stranding Network Database. Southwest Regional Office, National Marine Fisheries Service, CA

Nur N, Jahncke J, Herzog MP, Howar J and others (2011) Where the wild things are: predicting hotspots of seabird aggregations in the California Current System. Ecol Appl 21:2241-2257

Office of National Marine Sanctuaries (2009) Cordell Bank National Marine Sanctuary Condition Report. US Department of Commerce, National Oceanic and Atmospheric Administration, Office of National Marine Sanctuaries, Silver Spring, MD

Office of National Marine Sanctuaries (2010) Gulf of the Farallones National Marine Sanctuary Condition Report. US Department of Commerce, National Oceanic and Atmospheric Administration, Office of National Marine Sanctuaries, Silver Spring, MD

Pacific Fisheries Environmental Laboratory (2012) Upwelling/ environmental indices. Available at www.pfeg.noaa.gov (accessed 10 January 2012)

> Pinchuk AI, Coyle KO, Hopcroft RR (2008) Climate-related variability in abundance and reproduction of euphausiids in the northern Gulf of Alaska in 1998-2003. Prog Oceanogr 77:203-216

Potts JM, Elith J (2006) Comparing species abundance models. Ecol Model 199:153-163

- Rasmussen K, Palacios DM, Calambokidis J, Saborio MT and others (2007) Southern Hemisphere humpback whales wintering off Central America: insights from water temperature into the longest mammalian migration. Biol Lett 3:302-305

Redfern JV, Ferguson MC, Becker EA, Hyrenback KD and others (2006) Techniques for cetacean-habitat modeling. Mar Ecol Prog Ser 310:271-295

Redfern JV, Barlow J, Balance LT, Gerrodette T, Becker EA (2008) Absence of scale dependence in dolphin-habitat models for the eastern tropical Pacific Ocean. Mar Ecol Prog Ser 363:1-14

> Redfern JV, McKenna MF, Moore TJ, Calambokidis J and others (2013) Assessing the risk of ships striking large whales in marine spatial planning. Conserv Biol 27:292-302

Reese DC, Brodeur RD (2006) Identifying and characterizing biological hotspots in the northern California Current. Deep-Sea Res II 53:291-314

> Reeves R, Rosa C, George JC, Sheffield G, Moore M (2012) Implications of Arctic industrial growth and strategies to mitigate future vessel and fishing gear impacts on bowhead whales. Mar Policy 36:454-462

Reilly SB (1990) Seasonal changes in distribution and habitat differences among dolphins in the eastern tropical Pacific. Mar Ecol Prog Ser 66:1-11

Reilly SB, Fiedler PC (1994) Interannual variability of dolphin habitats in the eastern tropical Pacific. 1: Research vessel surveys, 1986-1990. Fish Bull 92:434-450

Reilly SB, Bannister JL, Best PB, Brown M and others (2008) Megaptera novaeangliae. In: IUCN 2011. IUCN Red List of Threatened Species. Version 2011.2. Available at www.iucnredlist.org (accessed 5 June 2012) 
Santora JA, Ralston S, Sydeman WJ (2011) Spatial organization of krill and seabirds in the central California Current. ICES J Mar Sci 68:1391-1402

Schwing FB, Bond NA, Bograd SJ, Mitchell T, Alexander MA, Mantua N (2006) Delayed coastal upwelling along the US west coast in 2005: a historical perspective. Geophys Res Lett 33:L22S01, doi:10.1029/2006GL 026911

Schwing FB, Mendelssohn R, Bograd SJ, Overland JE, Wang M, Ito S (2010) Climate change, teleconnection patterns, and regional processes forcing marine populations in the Pacific. J Mar Syst 79:245-257

Simard Y, Mackas DL (1989) Mesoscale aggregations of Euphausiid sound scattering layers on the continental shelf of Vancouver Island. Can J Fish Aquat Sci 46: 1238-1249

Sinclair EH, Moore SE, Friday NA, Zeppelin TK, Waite JM (2005) Do patterns of Steller sea lion (Eumetopias jubatus) diet, population trend and cetacean occurrence reflect oceanographic domains from the Alaska Peninsula to the central Aleutian Islands? Fish Oceanogr 14: 223-242

Statacorp (2007) Stata Statistical Software: Release 10, College Station, TX

Sydeman WJ, Bradley RW, Warzybok P, Abraham CL and others (2006) Planktivorous auklet Ptychoramphus aleuticus responses to ocean climate, 2005: unusual atmospheric blocking? Geophys Res Lett 33:L22S09, doi: 10.1029/2006GL026736

Thompson M (2009) Compiling AIS data from the U.S. Coast Guard's National AIS Program. Stellwagen Bank National Marine Sanctuary, Scituate, MA

- Trenberth KE (1984) Signal versus noise in the southern oscillation. Mon Weather Rev 112:326-332

Tynan CT, Ainley DG, Barth JA, Cowles TJ, Pierce SD, Spear LB (2005) Cetacean distributions relative to ocean processes in the northern California Current System. Deep-Sea Res II 52:145-167

Viddi FA, Hucke-Gaete R, Torres-Florez JP, Ribeiro S (2010) Spatial and seasonal variability in cetacean distribution

Editorial responsibility: Lisa Wedding,

Santa Cruz, California, USA in the fjords of northern Patagonia, Chile. ICES J Mar Sci 67:959-970

> Wade PR, Kennedy A, LeDuc R, Barlow J and others (2011) The world's smallest whale population? Biol Lett 7:83-85

Wiley DN, Thompson M, Pace RM III, Levenson J (2011) Modeling speed restrictions to mitigate lethal collisions between ships and whales in the Stellwagen Bank National Marine Sanctuary, USA. Biol Conserv 144: 2377-2381

Williams R, O'Hara P (2010) Modeling ship strike risk to fin, humpback and killer whales in British Columbia, Canada. J Cetacean Res Manag 11:1-8

Williams R, Thomas L (2007) Distribution and abundance of marine mammals in the coastal waters of $\mathrm{BC}$, Canada. J Cetacean Res Manag 9:15-28

Williams R, Gero S, Bejder L, Calambokidis J and others (2011) Underestimating the damage: interpreting cetacean carcass recoveries in the context of the Deepwater Horizon/BP incident. Conserv Lett 4:228-233

Wing SR, Botsford LW, Ralston SV, Largier JL (1998) Meroplanktonic distribution and circulation in a coastal retention zone of the northern California upwelling system. Limnol Oceanogr 43:1710-1721

Yau KKW, Wang K, Lee AH (2003) Zero inflated negative binomial mixed regression modeling of over-dispersed count data with extra zeros. Biometrical J 45:437-452

> Yen PPW, Sydeman WJ, Hyrenbach KD (2004) Marine birds and cetacean associations with bathymetric habitats and shallow-water topographies: implications for trophic transfer and conservation. J Mar Syst 50:79-99

Zuur AF, Ieno EN, Walker NJ, Saveliev AA, Smith GM (2009) Mixed effects models and extensions in ecology with R. Springer, New York, NY

Zuur AF, Ieno EN, Elphick CS (2010) A protocol for data exploration to avoid common statistical problems. Methods Ecol Evol 1:3-14

Zuur AF, Saveliev AA, Ieno EN (2013) Zero inflated models and generalized linear mixed models with R. Highland Statistics, Newburgh

Submitted: May 13, 2013; Accepted: June 12, 2014

Proofs received from author(s): October 9, 2014 